\title{
A synopsis of Westphalian-earliest Stephanian medullosalean and allied plant fossils from the Central and Western Bohemian basins, Czech Republic
}

\author{
ZBYNĚK ŠIMŮNeK \& Christopher J. CleAL
}

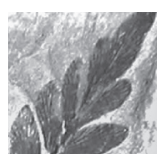

\begin{abstract}
The Medullosales were among the most diverse seed-plant clades in the Pennsylvanian palaeotropical, peat-forming wetlands and their fossil foliage constitutes valuable biostratigraphical and palaeofloristic indices. However, there have been several recent taxonomic revisions of the intramontane floras of the Central and Western Bohemian basins, as well as a number of unpublished records that were not incorporated into previous palaeogeographical studies. In this paper, we collate all of the currently available data on medullosalean foliage from the middle and upper Pennsylvanian Kladno Formation from these basins. The different autochthonous and allochthonous floras of the Radnice Member were coded separately to see if the habitats that represent may have had an effect on the analysis. The new dataset suggests that the roof shale floras, although still distinct from those of the lowland paralic basins, are more comparable to the similar aged intramontane Saar-Lorraine floras than was suggested previously. The apparent palaeofloristic difference between the Central and Western Bohemia and Saar-Lorraine floras seems to have been at least partly because the data for the former area included species from both ash deposits that representing peat substrate vegetation and roof shale floras representing clastic substrate vegetation. - Key words: Medullosan pteridosperms, Pennsylvanian, Radnice Member, Nýřany Member, Westphalian.
\end{abstract}

ŠIMŮNeK, Z. \& Cleal, C.J. 2020. A synopsis of Westphalian-earliest Stephanian medullosalean and allied plant fossils from the Central and Western Bohemian basins, Czech Republic. Bulletin of Geosciences 95(4), $441-468$ (12 figures, 2 tables, electronic supplement). Czech Geological Survey, Prague. ISSN 1214-1119. Manuscript received January 22 , 2020; accepted in revised form June 5, 2020; published online October 18, 2020; issued November 15, 2020

Zbyněk Šimůnek, Czech Geological Survey, Klárov 3/131, 11821 Praha, Czech Republic; zbynek.simunek@geology.cz• Christopher J. Cleal, Department of Natural Sciences, National Museum Wales, Cardiff CF10 3NP, UK

The Central and Western Bohemian basins were part of an intramontane depositional area in the Variscan Orogen, in which localised peat-forming wetlands developed in a high-elevation setting (Pešek 1994, 2004). The exact elevation remains uncertain but modelling of the palaeogeomorphology and drainage patterns by Opluštil (2005) suggested that they may have been up to $1000 \mathrm{~m}$ above sea-level, at least during middle Westphalian times. We will, therefore, refer to them as upland wetlands sensu Thomas \& Cleal (2017).

Abundant fossil floras in these deposits have attracted palaeobotanists since the early $19^{\text {th }}$ century (e.g. Sternberg $1820-1838$, Ettingshausen 1852, 1854) and are evidently the remains of vegetation broadly similar to that of the lowland paralic swamps of the Variscan foreland (e.g. Cleal 2018) but preserved in a higher-elevation, wetland setting. However, there are clear differences in the species present (Gothan 1915, 1951, 1954; Cleal 2008a, b) and it is now evident that these upland floras had an important influence on the overall dynamic evolution of the Euramerican peat swamp vegetation (Cleal 2008b, Cleal et al. 2009, Thomas \& Cleal 2017, Šimůnek \& Cleal 2018, Cleal \& Cascales-
Miñana 2019). Since there is increasing evidence that plant diversity fluctuations in these swamps either caused or were caused by climate change (e.g. Cleal \& Thomas 1999, 2005; Gastaldo et al. 1996; Pfefferkorn et al. 2008, 2017; Cleal et al. 2009, 2011) these vegetation dynamics are crucial for understanding the evolution of global life and environments at this time.

Some of the most diverse components of this swamp vegetation belonged to the Medullosales, an order of early gymnospermous seed-plants characterised by large, complex fronds, large ovules and a vascular system formed from a disected stele. There have several taxonomic studies on the foliage of these plants in the Central and Western Bohemian basins (Němejc 1936, 1949; Havlena 1953; Šimůnek 1988, 2004, 2007; Šimůnek \& Cleal 2002, 2004, $2011,2013)$ but there has been no synoptic analysis of the group as a whole. The aim of this paper is to present the first such analysis for the Middle Pennsylvanian-age Kladno Formation of the Central and Western Bohemian basins. We have included those taxa for which there is strong evidence of medullosalean affinities (e.g. Neuropteris Brongniart, Alethopteris Sternberg), as well as a few 
whose affinities are less well-established but are usually linked with this order (e.g. Havlenaea Šimůnek \& Cleal). We re-examine the relationship between these floras and those of the lowland areas of the Variscan foreland and of the other intramontane areas. Does this require the floristic model of Cleal (2008a, b) to be modified, and does it throw any new light on the dispersal patterns of these species and the palaeoecology of these important coal basins?

Through the rest of the paper, we will use the accronym CWBB for the Central and Western Bohemian basins. The term Variscan Euramerica refers to Variscan Orogen, and its associated foreland area and intramontane basins (Cleal 2008b). The chronostratigraphy used is what is widely referred to as the Heerlen regional scheme as summarised by Wagner (1974) (Fig. 1).

\section{Geological background and localities}

Pennsylvanian-age coal-bearing deposits occur in the Bohemian Massif in a series of coalfields, from west to east known as the Plzeň, Manětín, Kladno-Rakovník, Radnice, Žihle, and Mšeno-Roudnice basins (Pešek 2004) (Fig. 2). The Bohemian Massif was formed though crustal thickening and uplift as part of the Variscan Orogeny, and for a time was at elevations of $2-3 \mathrm{~km}$ above sea-level (Opluštil et al. 2013). However, subsequent gravitational collapse and erosion substantially lowered the elevation, and then normal and/or strike-slip faulting in late middle-late Westphalian times resulted in a complex depositional basin to form. During this initial time of sediment deposition, the area was probably at an elevation of up to $c .1,000 \mathrm{~m}$ above sea level (Opluštil 2005). The resulting lithosome consists of a range of alluvial deposits alternating with coals. The Westphalian-earliest Stephanian part of the sequence is assigned to the Kladno Formation, with two subdivisions, the Radnice and Nýrany members.

\section{Radnice Member}

The Radnice Member (e.g. Němejc 1953, Wagner 1977, Šimůnek in Pešek 2004, Opluštil et al. 2016) belongs to the Paripteris linguaefolia Zone sensu Wagner (1984) and probably the lower (Neuropteris semireticulata) subzone sensu Cleal (1991) and Cleal \& Thomas (1994). This indicates a late Duckmantian or early Bolsovian age (Opluštil et al. 2016). For the purposes of this analysis, eight fossiliferous units are recognised (Fig. 3, Tab. 1).

Roof shales in Plzeň coal group. - These stratigraphically lowest coals in the region are only locally developed, mainly in the Plzeň and Merklín basins. There are between

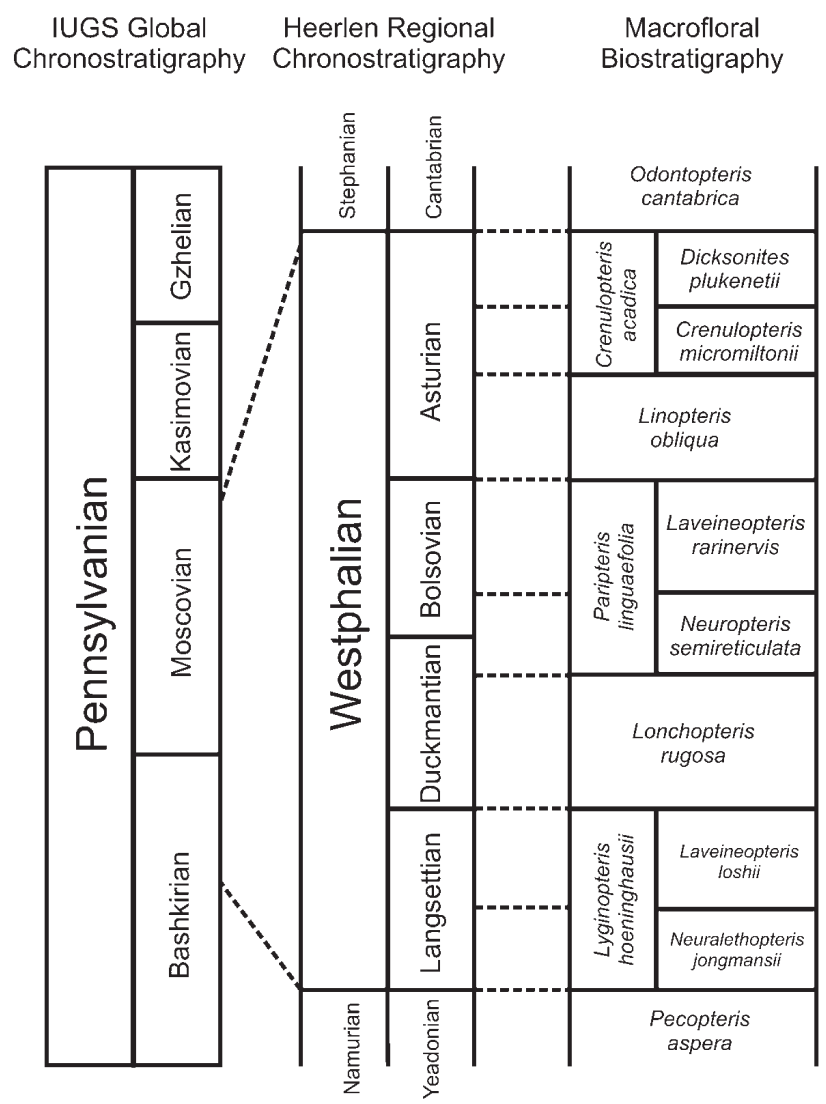

Figure 1. Summary of the Pennsylvanian stages in the IUGS Global Stratigraphic Scheme, the stages and substages in the Heerelen Regional Chronostratigraphy used in Europe (Wagner 1974), and the plant biozones developed by Wagner (1984) and modified by Cleal (1991). From Cleal \& Cascales-Miñana (2019, fig. 2).

two to five coal seams in the group, whose roof shale yields mostly parautochthonous floras. Notable occurrences in the Plzeň Basin are in ironstone nodules at Bílá Hora and Blatnice, and shales at the Krimich I Mine (NýranyPankrác), Merklín relic.

Whetstone Horizon (Bèlka tuff). - The main coal reserves in the region are the Lower and Upper Radnice seams in the lower Radnice Member, up to $8 \mathrm{~m}$ and $14 \mathrm{~m}$ thick respectively (Pešek 1994). The two seams are separated by a 3-7 $\mathrm{m}$ thick tuffaceous deposits known as the Whetstone Horizon, which is found in all the coalfields in the CWBB where the Radnice coal group are mined.

The Whetstone Horizon normally consists of two layers. The lowermost layer (0.4-0.6 m thick) of yellow to white tuff known as Bělka represents a single volcanic ash fall that buried the landscape, and contains autochthonous remains of the peat substrate vegetation (Opluštil et al. 2007, 2009a, b, 2014); it has been dated at c. $314.3 \mathrm{Ma}$ (Opluštil et al. 2016) and thus of late Duckmantian (= early Moscovian) age. The upper layer consists of 
laminated tuffites and tuffaceous mudstones known as Brousek (Whetstone). This represents re-worked ash deposits (Opluštil et al. 2009a) containing a mixture of autochthonous remains of plants that were left protruding out of the ash deposits, parautochthonous remains caught up during the re-working of the ash, and allochthonous remains of extra-basinal vegetation.

The Whetstone Horizon has long been known as a classic source of plant fossils, especially from the Radnice Basin from where Sternberg (1821, 1823, 1825, 1833, 1838 ) described many specimens (notably from Svinná see also Opluštil et al. 2007) and where there have been major recent excavations at Ovčín-Přívětice (Opluštil et al. 2009a, b, 2014). Other major palaeobotanical sites are the Stradonice locality in the Lísek relic (Ettingshausen 1852); and localities in the Plzeň Basin (Nýřany, Uxa mine, Blatnice, Marie and Prokop mines), Kladno-Rakovník Basin (Kladno, Prago III Mine), and the Malé Př́ilepy and Štilec relics (Opluštil et al. 2007).

Tuffaceous intercalations ("Opuky") in Upper Radnice Seam. - These are thinner volcanic layers within the Upper Radnice Seam found mainly near the southern margins of the Kladno-Rakovník and Radnice basins (Pešek 1994). There are seven "opuka" intercalations in the Kladno-Rakovník Basin, whereas the Radnice Basin has only four that tend to have lower ash content. One of the tuffaceous layers in the Kladno-Rakovník Basin has been dated at c. $313.8 \mathrm{Ma}$ (Opluštil et al. 2016) and thus also of late Duckmantian (= early Moscovian) age. Macrofloras are especially well- known from the Ronna and Schoeller mines near Kladno, and the František Mine at Otovice (Opluštil et al. 2007). The fossils described by Sternberg $(1820,1821,1825,1838)$ from Břasy in the Radnice Basin are also probably from this level and were included in the "Opuky" records.

Roof shale ("Mydláky") of Upper Radnice Seam. - Wherever the Upper Radnice Seam has been worked, the roof shales have often yielded well-preserved parautochthonous floras (Pšenička \& Opluštil 2011). Notable discoveries in the Radnice Basin were made at Mostiště and Vranovice (Sternberg 1820, 1821, 1825; Ettingshausen 1854). There have also been discoveries in the Plzeň and Kladno-Rakovník basins (in above mentioned mines), and in the Lísek and Merklín relics.

Tuff, tuffites and roof shales associated with Lubná coal group. - The upper Radnice Member containing the Lubná coals is separated from the Radnice coal group by a non-sequence and is regarded as somewhat younger (Opluštil et al. 2016). The coals contain a number of tuff and tuffite intercalations, the best developed being the Z-tuff within the Upper Lubná Seam; this tuff is rather coarse and includes some autochtonous remains. A number of the tuffs have been dated and tend to give ages of c. $312.4 \mathrm{Ma}$ (Opluštil et al. 2016) and thus of early Bolsovian (= early Moscovian) age. Plant fossils are best known from the Kladno-Rakovník Basin (the Rako and Ludvík mines, and the Filip II quarry), where they occur in both the roof shales, and intra-seam tuffs and tuffites.
Figure 2. Map of West and Central Bohemia basin showing main areas mentioned in text. Redrawn from Opluštil et al. (2005).

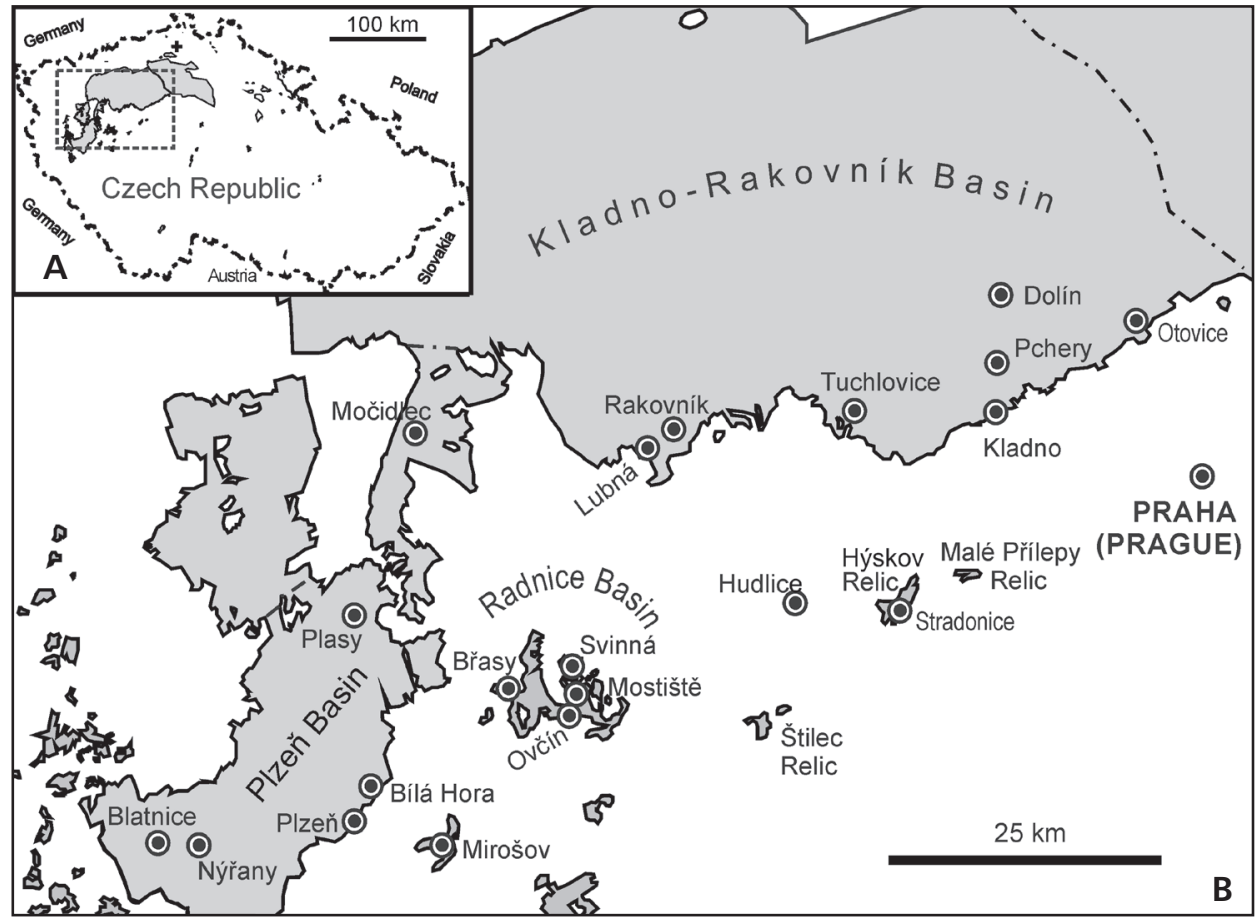




\section{Nýřany Member}

This is quite different from the underlying Radnice Member, consisting of up to $450 \mathrm{~m}$ of higher energy, braided fluvial deposits, with thinner, less persistent coal seams (Opluštil et al. 2005, Bashforth et al. 2011). The coals are best developed in the Plzeň and Kladno-Rakovník basins, although the sequences in these two areas are difficult to correlate (Opluštil et al. 2016). Nevertheless, three intervals with distinct macrofloras are generally recognised. Some evidence of autochthonous plant remains was reported by Bashforth et al. (2011) as in situ stems, but the medullosalean remains appear to be parautochthonous or allochthonous. The oldest is the Mirošov Horizon (Němejc 1938), which is partly conglomeratic, but also locally includes mudstones containing plant remains. This is separated by a nonsequence from the Touškov, Nýřany and Chotíkov coal groups, in which plant fossils are known from both the roof shales and inter-seam mudstones. These stratigraphically lower two floras of the Nýrany Member belong to the upper Crenulopteris acadica Zone (sensu Wittry et al. 2015 - formerly named the Lobatopteris vestita Zone sensu Wagner 1984), which indicate a late Asturian age. Tuffs in the lower Nýrany Member interval have been dated at $c$. 308.0 Ma and c. 307.0 Ma (Opluštil et al. 2016) and thus of late Moscovian age.

The stratigraphically youngest part of the member includes the Nevřen Group of coals. The floras here are essentially similar to those of the lower Nýřany Member, except for the presence of Sphenophyllum oblongifolium (Germar \& Kaulfuss) Unger (e.g. Šetlík 1977, Opluštil et al. 2016), which suggests the Odontopteris cantabrica Zone of Cantabrian age (Wagner 1984, Cleal et al. 2003). A tuff has in this interval been dated at 306.0 Ma (Opluštil et al. 2016), of early Kasimovian age.

Plant fossils were described from the Nýřany Member by Sternberg $(1825,1838)$, from Mirošov and Plasy near Plzeň. The floras from here were also reviewed by Ryba (1904) and Bashforth et al. (2011).

\section{Methods}

A comprehensive review was made of the literature recording medullosalean foliage remains from the CWBB. This was combined with data derived from collections in the Czech Geological Survey, Prague (CGS) and the National Museum. Prague (NMP). The data were collated and grouped based on their relative stratigraphical positions, and according to facies criteria, such as those found in roof shales above coal seams, and those found in various tuff and tuffite horizons.

The resulting binary, presence/absence were then integrated with the dataset used by Cleal (2008b) in his study of medullosalean floristics of the various basins of Variscan Euramerica, which had been modified as described in the Discussion section of the paper (the revised data are provided as a supplementary file). The palaeofloristic analyses were carried out using the same numerical methods as in Cleal $(2008 \mathrm{a}, \mathrm{b})$. The order of the basins in the matrix was adjusted following an unconstrained seriation analysis. They were then analysed by cluster analysis (using the Unweighted Pair-Group Average algorithm and Raup-Crick similarity indices) and ordination analysis (Detrended Correspondence Analysis - DCA). The significance of the taxonomic differences between some of the observed grouping was tested using non-parametric Multivariate Analysis of Variance (PERMANOVA - Anderson 2001, Anderson \& Walsh 2013).

\section{Taxonomic notes}

The following is not intended as a complete systematic analysis but is an inventory with notes of the species that have been recognised in the Kladno Formation. In most cases the records are based on well-established published data, which are listed in the synonymy lists. These synonymy lists have been annotated using a system similar to that used in Cleal \& Shute (1995): the first valid publication of the name as used here is marked "§"; the first valid publication of the basionym is marked "**; and illustrated specimens from the CWBB are marked "q". If a species is being recorded with a "cf.", the protologue will not be included in the quoted synonymy and so its author and date of publication will be given in the subheading for that species. Where possible, the species are placed in the suprageneric groups (fossil-families) as summarised by Cleal \& Shute (2003).

Family Alethopteridaceae

Remarks. - This fossil-family comprises the fronds with a bifurcate-pinnate architecture sensu Laveine (1997) that have a major proximal bifurcation, but lack intercalated pinnae and cyclopterids.

\section{Alethopteris distantinervosa Wagner}

Figure 4A, B

\1936 Alethopteris grandini Brongniart. - Němejc (non Brongniart), pl. 2, fig. 3.

$\S 1968$ Alethopteris distantinervosa; Wagner, p. 61, text-fig. 12; pl. 16.

『1977 Alethopteris distantinervosa Wagner. - Šetlík, pl. 3, fig. 2.

"1988 Alethopteris grandinioides Kessler var. distantinervosa Wagner. - Šimůnek, text-figs 4-6; pls 3-6; pl. 7, figs $1-5$. 
Figure 3. Generalised lithostratigraphy of the Kladno Formation. Thicknesses vary considerably across the basin and those shown here are only intended to be indicative. Adapted and redrawn from Opluštil et al. (2005) and Šimůnek \& Cleal (2011).
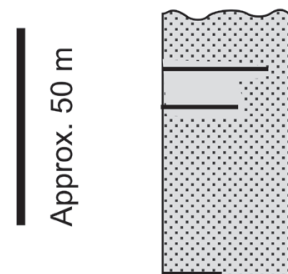

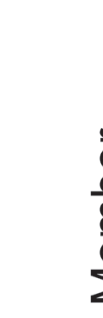
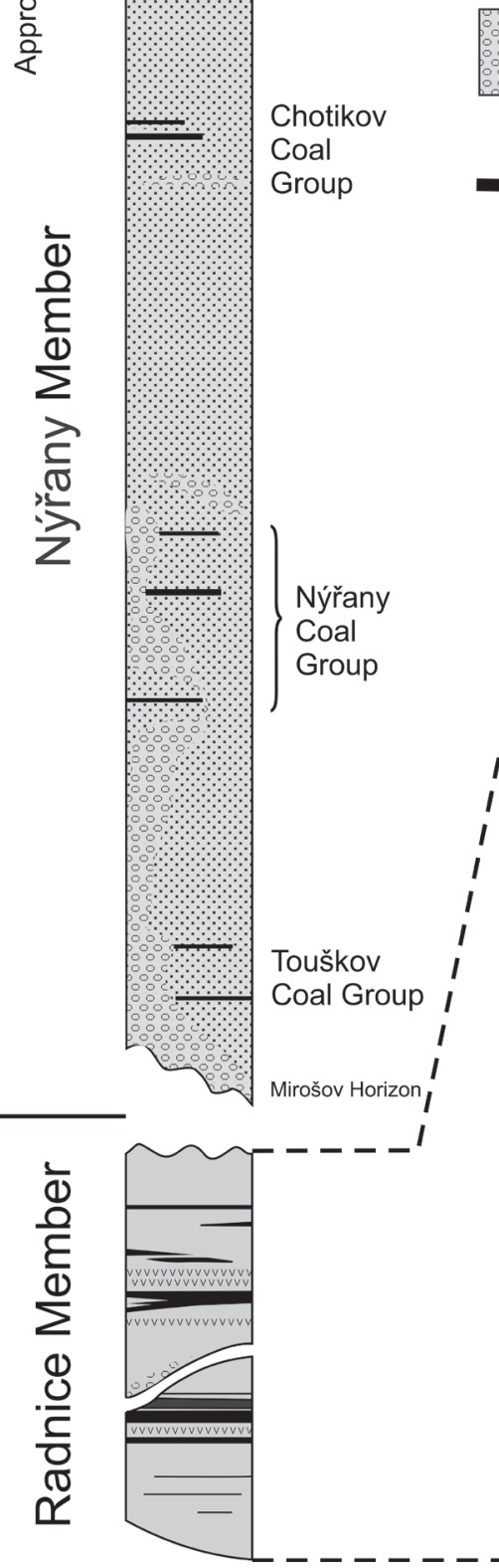

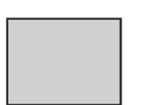

Predominantly argillaceous

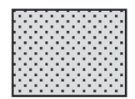

Predominantly arenacous

$\int$ Group

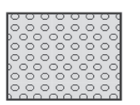

Predominantly conglomeratic

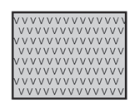

Ash bands
Coal

Seams 
rian of the more lowland basins (e.g. Britain, northern Spain, Canadian Maritimes). The present record is based on a single specimen with cuticles, with epidermal structures very similar to that seen in the types of this species. However, this Kladno Formation specimen is stratigraphically rather older than the normally observed range of this species, in the Crenulopteris acadica and Odontopteris cantabrica zones (Wagner 1968).

\section{Alethopteris kettneri Havlena}

Figure 5A, B

\$1951 Alethopteris kettneri; Havlena, p. 499, pl. 1, figs 1, 2.

\1988 Alethopteris grandinioides Kessler var. kettneri (Havlena). - Šimůnek, text-fig. 7; pl. 7, fig. 6; pl. 8.

Remarks. - As demonstrated by Šimůnek (1988) this belongs to the complex of species centred on what is now named Alethopteris pseudograndinioides (A. grandinioides auct.). However, it differs from the latter species in the veins being significantly more oblique to the pinnule margin and having a much lower vein density (18-22 veins per $\mathrm{cm}$ on the pinnule margin). It occurs in the Nýřany Member of the Plzeň Basin.

\section{Alethopteris lonchitica Schlotheim ex Sternberg} Figure 4C, D

1820 Filicites lonchiticus; Schlotheim, p. 411. [nom. illegit.]

$\$ 1825$ Alethopteris lonchitica; Schlotheim ex Sternberg, p. 21.

『1854 Alethopteris Sternbergii Goeppert. - Ettingshausen, pp. 42, 43, pl. 18, fig. 4 .

"1936 Alethopteris lonchitifolia P. Bertrand. - Němejc, pp. 14-17, text-fig. 9a, b.

ๆ2007 Alethopteris lonchitica; Opluštil et al. - Šimůnek, pl. 8 , fig. 4.

†2007 Alethopteris lonchitica Sternberg. - Šimůnek, p. 394, pl. 5, fig. 2.

Remarks. - We are using this name in the sense of Zodrow \& Cleal (1998) for the species with relatively large pinnules and dense, non-flexuous veins found mainly in upper Westphalian and lower Stephanian floras of Euramerica; and not for the mainly lower Westphalian species that
Wagner \& Álvarez-Vázquez (2008) showed to be more correctly named Alethopteris urophylla (Brongniart) Göppert. However, we have not followed the opinion of Wagner \& Álvarez-Vázquez (2008) that the name A. lonchitica should be applied to the species traditionally called Alethopteris ambigua Lesquereux.

The specimens from the CWBB are mostly from the Radnice Member but a specimen is also known in the lower Nýřany Member. Cuticles described by Šimůnek (2007) showed epidermal structures very similar to those described by Barthel (1962) from the type region for A. lonchitica - Saar-Lorraine.

\section{Alethopteris cf. serlii (Brongniart) Göppert, 1836}

Figure 4E, F

ף1936 Alethopteris Serli Brongniart. - Němejc, text-fig. 8; pl. 2, fig. 4.

ๆ2007 Alethopteris serlii (Brongniart) Göppert. - Šimůnek, pl. 2, fig. 9; pl. 5 , fig. 4 .

Remarks. - This species, which is normally characterised by relatively robust pinnules compared with most other Alethopteris species, and fine, often somewhat flexuous veins, usually occurs in upper Asturian to lower Cantabrian floras (see discussion in Zodrow \& Cleal 1998). The pinnules from the CWBB assigned to A. serlii by Šimůnek (2007) were very similar in shape to the types of that species (e.g. Wagner 1968) and yielded cuticles very similar to those described by Zodrow \& Cleal (1998) from the Sydney Coalfield. The only noticeable morphological difference was that the venation in the Bohemian specimens was not quite as flexuous, but this feature can be variable in $A$. serlii. This record is of interest as the rest of the associated flora suggests a rather older age than is normal seen for A. serlii (e.g. Zodrow \& Cleal 1998) the Radnice coal group, Bolsovian. For these reasons we have referred these specimens from Bohemia to $A$. cf. serlii.

\section{Alethopteris nemejcii Wagner}

Figure 6A

ף1936 Alethopteris valida Boulay. - Němejc (non Boulay), text-fig. 7; pl. 1, fig. 2.

Figure 4. Medullosalean frond fragments from the Kladno Formation, Central and Western Bohemian basins. • A, B - Alethopteris distantinervosa Wagner; A - Kladno locality, Whetstone Horizon, (as Alethopteris grandinioides Kessler by Šimůnek, 1988, pl. 3, fig. 1, Pchery locality, Theodor Mine, coll. CGS, No. ZŠ 850); B -, macerated isolated pinnule with venation, Ovčín near Radnice locality, Whetstone Horizon. • C, D - Alethopteris lonchitica Schlotheim ex Sternberg; C- Radnice locality, Matylda Mine, Whetstone Horizon (coll. CGS, No. ZŠ 848); D - pinnule fragment with venation, Whetstone Horizon, Kladno locality, Prago III Mine. • E, F - Alethopteris cf. serlii (Brongniart) Göppert, Břasy near Radnice locality, Mr. Stárek's quarry, Radnice Member, National Museum Prague, No. E 7634. • G - Alethopteris cf. pseudograndinioides Zodrow et Cleal, Lubná near Rakovník, Filip II Quarry, Radnice Member, Lubná Group of coals, Kladno-Rakovník Basin, Bolsovian. No. ZŠ 793b (photo: Šimůnek \& Cleal 2018, pl. 1, fig. 2). Scale bars: A, C, E = 1 cm; B, D = $2 \mathrm{~mm}$; and F, G = $5 \mathrm{~mm}$. 


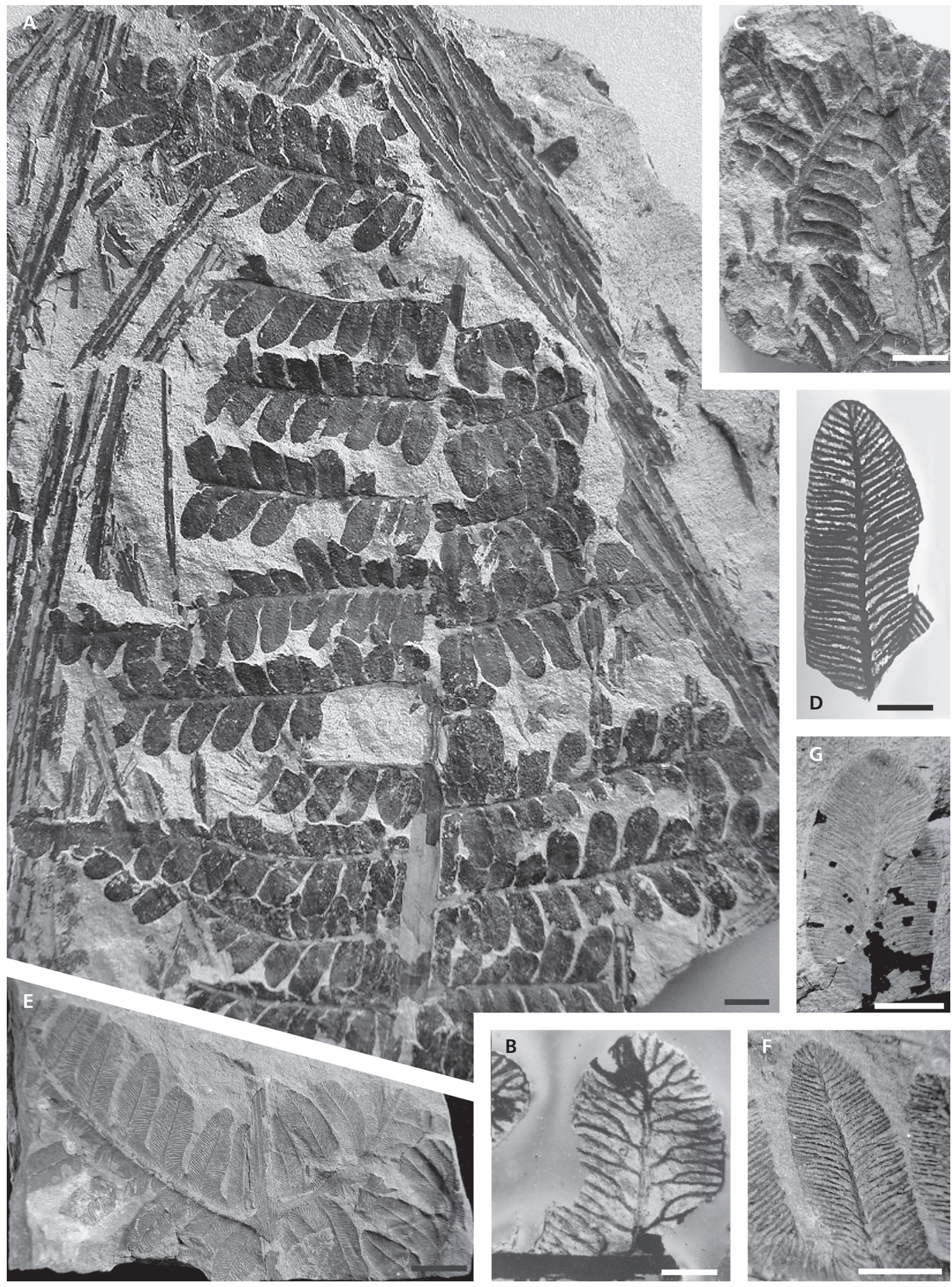


\$1968 Alethopteris nemejcii; Wagner, p. 111, text-fig. 32; pl. 41, figs 119-122.

『2007 Alethopteris nemejcii Wagner. - Šimůnek, pl. 2, figs $10-12$; pl. 5, fig. 3.

Remarks. - This species was based on specimens from the CWBB that were originally identified as A. valida, but which had more triangular pinnules and denser veins. Some of the cuticles described by Šimůnek (2007) originated from the same locality that yielded the holotype of this species - Kamenný Újezd, Lazarus mine. This species occur in the Radnice Member (Duckmantian) at many localities in the Plzeň Basin and Merklín relic.

\section{Lonchopteris rugosa Brongniart}

Figure 6B

$\$ 1836$ Lonchopteris rugose; Brongniart, p. 368.

"1876 Lonchopteris rugosa Brongniart. - Feistmantel, pl. 67 , figs 7,8 .

ๆ2007 Lonchopteris rugosa Brongniart. - Šimůnek, pl. 3, fig. 1 ; pl. 5 , fig. 5 .

Remarks. - Alethopteroid pinnules with anastomosed veining are widespread but generally rarer that true Alethopteris. As with most alethopteroids, the pinnules show considerable morphological variation resulting in several species having been recognised. However, Buisine (1961) has shown that venation is a more reliable taxonomic character, and that most fronds with relatively isodiametric vein meshes such as those from CWBB belong to L. rugosa. There is also an unillustrated record from near Plzeň by Němejc (1941, p. 213) of Lonchopteris chandesrisii Bertrand, 1932, a species with more elongate vein meshes, but which has otherwise only been recorded Saar-Loraine (e.g. Bertrand 1932). This record may have been based on a poorly preserved specimen in his collection that was labelled as this species, and which originated from the Whetstone Horizon at Svinná. However, this specimen does not show the venation clearly enough to verify the identification. Lonchopteris rugosa is not very common in CWBB. It occurs in the Radnice Member of the Plzeň and Radnice Basin, but famous are samples from the Whetstone Horizon (Brousek) of the Stradonice locality, Hýskov relic.

Family Neurodontopteridaceae

Remarks. - This fossil-family comprises fronds with a bifurcate semi-pinnate architecture sensu Laveine (1997) that have a major proximal bifurcation and intercalated pinnae on the primary rachis branches. The proximal part of the frond lacks true cyclopterids, although there may be fused pinnae in this part of the frond (sometimes referred to as forma impar pinnae sensu Shute \& Cleal 2002).

\section{Macroneuropteris scheuchzeri (Hoffmann) Cleal et al.} Figure 7A

*1827 Neuropteris Scheuchzeri; Hoffmann, p. 157, pl. 1b, figs $1-4$.

ฯ1854 Neuropteris acutifolia Brongniart. - Ettingshausen, pl. 18, fig. 5.

\1953 Neuropteris Scheuchzeri Hoffmann. - Havlena, pl. 7, fig. 2; pl. 8, figs 4, 5 .

$\S 1990$ Macroneuropteris scheuchzeri (Hoffmann). - Cleal et al., p. 488.

`2007 Macroneuropteris scheuchzeri (Hoffmann) Cleal et al. - Šimůnek, pl. 4, figs 5-8; pl. 5, fig. 8.

"2011 Macroneuropteris scheuchzeri (Hoffmann) Cleal et al. - Šimůnek \& Cleal, pls 18, 19; pl. 21, fig. 1.

Remarks. - Isolated, large pinnules with strongly marked epidermal hairs occur frequently in many upper Westphalian and lower Stephanian floras of Europe, but there were few records in the early literature on the CWBB palaeobotany. However, Havlena (1953) figured specimens from the Radnice Member, which he compared with the var. nordfrancia of Bertrand (1930). He also recorded but did not figure it from the Nýřany Member.

The specimen figured as $N$. acutifolia by Ettingshausen (1854) was transferred to N. plicata by Havlena (1953). However, this specimen with several large acute pinnules is from the Mostitz (Mostiště) locality in the Radnice Basin, where only the Radnice Member occurs. In our view, this specimen is more likely to belong to Macroneuropteris scheuchzeri.

\section{Neuropteris plicata Sternberg}

Figure 6E

$\S 1825$ Neuropteris plicata; Sternberg, p. 14 (tent.).

`1833 Neuropteris plicata Sternberg. - Sternberg, pl. 19, figs $1,3$.

\1833 Neuropteris acutifolia Sternberg. - Sternberg, pl. 19, fig. 4.

『1833 Neuropteris obovata Sternberg. - Sternberg, pl. 19, fig. 2.

"1904 Neuropteris planchardii (Zeiller). - Ryba (non Zeiller), pl. 15, fig. 3.

? \1904 Neuropteris obliqua (Brongniart). - Ryba (non Zeiller), pl. 16, fig. 2.

『1922 Neuropteris plicata Sternberg. - Šetlík, figs 1-3.

ף1949 Mixoneura plicata (Sternberg). - Němejc, pl. 5, figs $1-5$.

\1949 Mixoneura britannica (Gutbier) Zeiller. - Němejc (non Gutbier), pl. 4, figs 8-14.

\1994 Neuropteris plicata Sternberg. - Šimůnek, pl. 3, fig. 3.

`2011 Neuropteris plicata Sternberg. - Bashforth et al., pl. 3, fig. 1 . 

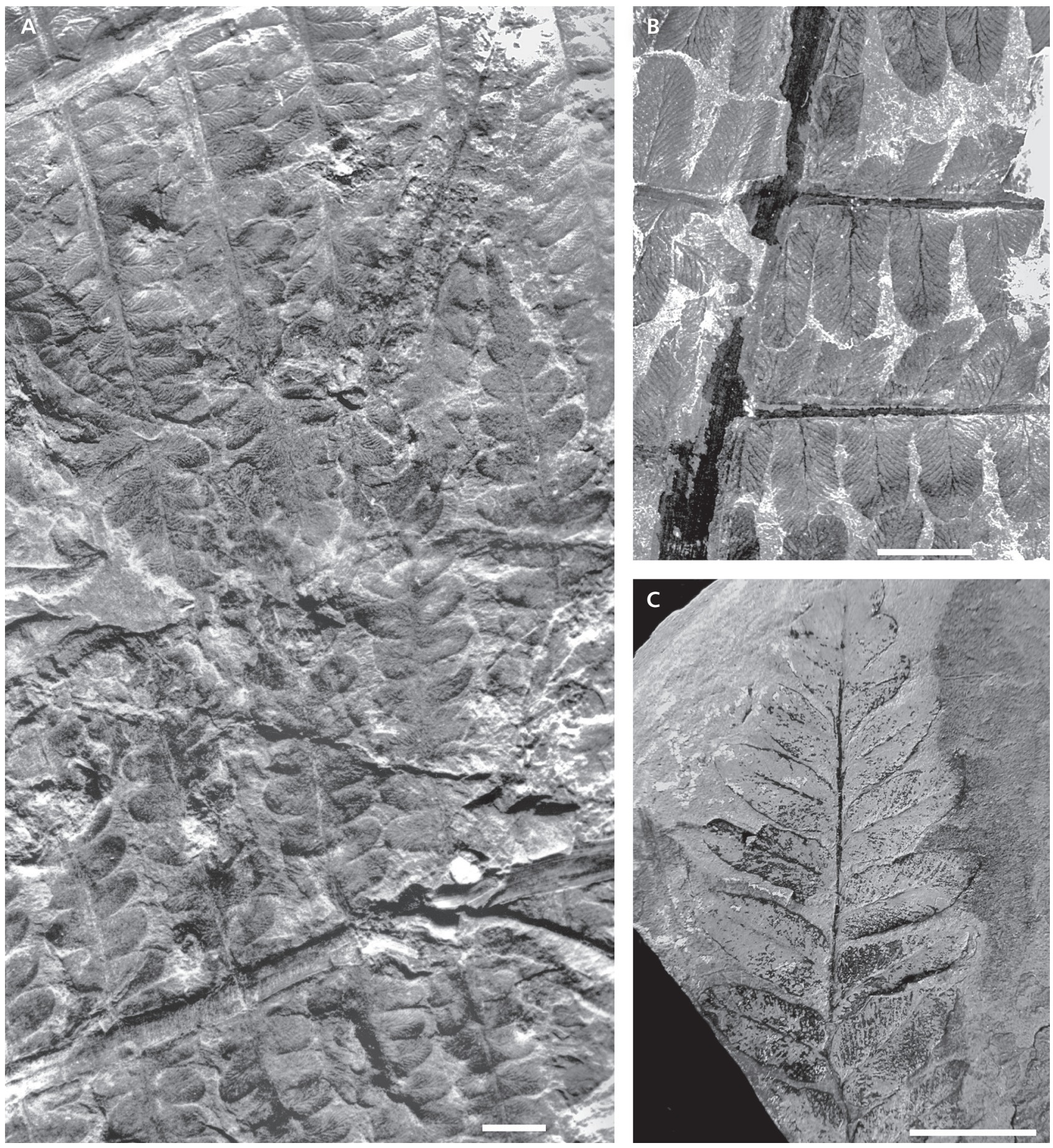

Figure 5. Medullosalean frond fragments from the Kladno Formation, Central and Western Bohemian basins. • A, B - Alethopteris kettneri Havlena, Nýřany locality, Krimich I Mine, Plzeň Basin, Nýřany coal group, Asturian, (Havlena 1951, pl. 1, figs 1, 2; Šimůnek 1988, pls 7, 8, fig. 6); B - coll. Dept. of Palaeontology, Fac. of Sciences, Charles University, Prague. • C - Havlenaea coriacea (Ettingshausen) Šimůnek \& Cleal, Radnice Member, Stradonice (NMP E 4152, Barrande coll.). Scale bars $=1 \mathrm{~cm}$.

92011 Neuropteris planchardii Zeiller. - Bashforth et al. (non Zeiller), pl. 2, fig. 14.

Remarks. - The variation in N. plicata and the resulting confusion in early taxonomic studies was discussed by
Šetlík (1922). Němejc (1949) later transferred the species to Mixoneura in the sense of Bertrand (1930), for the group of species allied to Neuropteris ovata Hoffmann, but Laveine \& Legrand (2019) have shown this to be an invalid use of the generic name; it should more correctly 
be retained in Neuropteris (e.g. see Cleal \& Shute 1995). Ryba (1904) described pinnae from the Nýřany Member as $N$. planchardii but that species is normally found in middle Stephanian floras. The illustration is rather unclear but the shape of the pinnules resembles $N$. plicata, which is well documented from these floras.

Němejc (1949) suggested that the specimens he assigned to M. britannica are very similar to Neuropteris plicata except that the vein density is much lower. However, the vein density of Němejc's specimens (40-50 veins per $\mathrm{cm}$ on pinnule margin) fall within the normally accepted range of this group of neuropterids (Saltzwedel 1969). The specimen figured as $N$. obliqua by Ryba (1904) is indeterminate but has a pinnule shape similar to N. plicata.

There is ongoing uncertainty as to the taxonomic position of this species relative to Neuropteris ovata Hoffmann, 1827, which has very similar shaped pinnules and venation to N. plicata (e.g. Saltzwedel, 1969). If these two species names did prove to be synonyms then Sternberg's would take precedence over the much more widely used $N$. ovata. However, the latter species is being increasingly circumscribed by cuticular data (e.g. Barthel 1962, Cleal \& Zodrow 1989, D'Angelo \& Zodrow 2016, Šimůnek \& Cleal 2016) which is impossible to obtain from the types of $N$. plicata, which are impressions. For the purposes of this study were have therefore maintained the two species as separate, although the possibility of their synonymy was considered in the floristic analysis discussed later.

\section{Odontopteris reichiana Gutbier}

Figure 8D, E

$\S 1835$ Odontopteris reichiana; Gutbier, p. 65

ॠ1949 Odontopteris reichiana Gutbier. - Němejc, pl. 1, fig. 9; pl. 2, fig. 5 .

ๆ2011 Odontopteris reichiana Gutbier. - Bashforth et al., pl. 2, fig. 13.

Remarks. - The relatively small fronds of Odontopteris usually appear first at about the Westphalian-Stephanian boundary. Several species have been recognised, and their taxonomy has been reviewed by Šimůnek \& Cleal (2004) based on their pinnule morphology and epidermal structure. The only recorded specimens of $O$. reichiana from CWBB were figured by Němejc (1949) and Bashforth et al. (2011), and it has been impossible to obtain cuticles from them. Nevertheless, they are morphologically very similar to the types of this species from Zwickau. Laveine \& Oudoire (2016) have argued that this species is conspecific with Odontopteris brardii Brongniart but for the reasons explained by Šimůnek \& Cleal (2004) we have maintained them as separate. Odontopteris reichiana is relatively rare species in the Nýrany Member of the CWBB.
Family Cyclopteridaceae

Remarks. - This fossil-family comprises fronds with a bifurcate semi-pinnate architecture sensu Laveine (1997) that have a major proximal bifurcation and intercalated pinnae on the primary rachis branches. Unlike the Neurodontopteridaceae, however, they have true cyclopterids in the proximal part of the frond.

\section{Callipteridium rubescens (Presl ex Sternberg) Wagner ex Bashforth et al.}

Figure 7C

*1838 Neuropteris rubescens; Presl ex Sternberg, p. 136, pl. 50, fig. $1 \mathrm{~b}$.

『1904 Alethopteris (Asterotheca) subdavreuxii (Sterzel). Ryba (non Sterzel), pl. 15, fig. 2.

\1929 Alethopteris rubescens (Sternberg). - Němejc, pl. 1, figs 6-8.

^1931 Alethopteris rubescens (Sternberg). - Němejc, pl. 1, fig. 1.

"1936 Alethopteris rubescens (Sternberg). - Němejc, text-fig. 4; pl. 2, figs 1, 2.

$\$ 1963$ Callipteridium rubescens (Sternberg). - Wagner, p. 721.

ॠ1977 Praecallipteridium rubescens (Sternberg). - Šetlík, pl. 8, fig. 1.

ๆ2011 Callipteridium rubescens (Presl in Sternberg) Wagner. - Bashforth et al., pl. 2, fig. 7.

Remarks. - The type of this name is from Plasy, near Plzeň, and has been refigured by Němejc (1929, pl. 1, fig. 6) and Kvaček \& Straková (1997, pl. 42, fig. 2b). Němejc (1929) showed that this species has nothing to do with Neuropteris and Wagner (1963) suggested that it should be transferred to Callipteridium. Němejc (1931) later described ovules associated with this species.

This species is very similar to Callipteridium jongmansii (Bertrand) Wagner, 1962, which has been extensively recorded from the upper Asturian of Europe (e.g. Bertrand 1932, Wagner 1966, Laveine et al. 1977). It has been suggested that the names are conspecific (A. Bashforth, personal communication 2007) but the problem has yet to be the subject of a detailed published taxonomic analysis. This species is very common in the Nýřany Member of the CWBB.

\section{Callipteridium armasii (Zeiller) Wagner}

Figure 9A

ๆ2008 Callipteridium cf. armasii (Zeiller) Wagner. - Šimůnek, fig. 16.4 .

Remarks. - This record from the Nevřeň coal group of the Nýrany Member is based on specimens with smaller pin- 

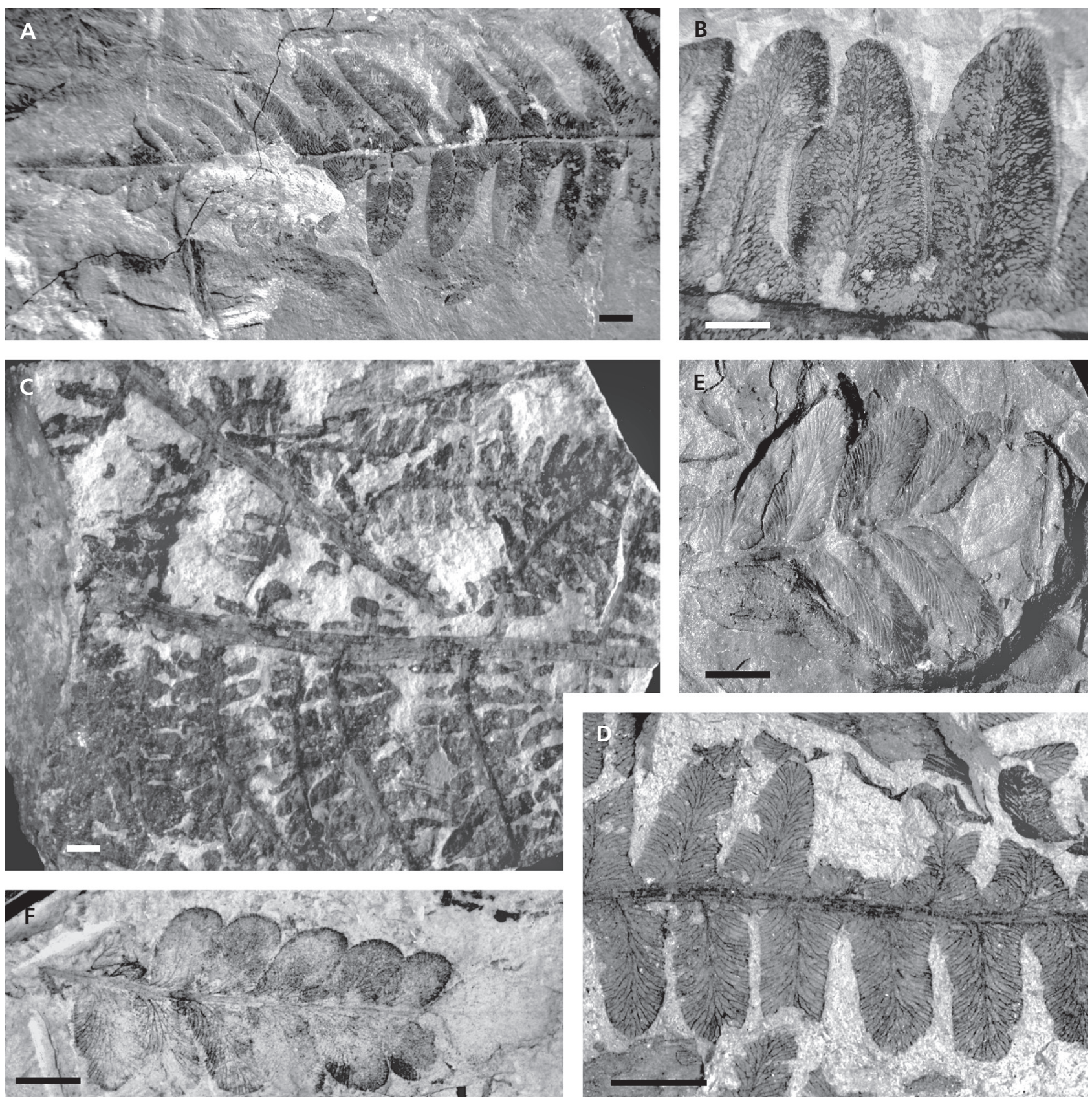

Figure 6. Medullosalean frond fragments from the Kladno Formation, Central and Western Bohemian basins. - A - Alethopteris nemejcii Wagner, Radnice Member, Nýřany locality, Krimich Mine, coal seam 3, NMP, No. E 7633. • B - Lonchopteris rugosa Brongniart, Radnice Member, Nýřany locality, Krimich Mine, coal seam 3, NMP, No. E 1250. C, D - Palaeoweichselia defrancei (Brongniart) Potonié \& Gothan, Whetstone Horizon, Malé Př́lepy relic, NMP No. E 1302. E - Laveineopteris hollandica (Stockmans) Cleal \& Shute, Radnice Member, Dolín locality, Dl 1 borehole, 1099 , 3-1100 m, Kladno-Rakovník Basin, CGS, No. JŠ 179. • F - Neuropteris plicata Sternberg (previously identified as Mixoneura britannica (Gutbier) Zeiller), Nýřany Member, Rakovník-Šamotka locality, Moritz Mine, Kladno-Rakovník Basin, NMP, No. E 6055. All scale bars $=5 \mathrm{~mm}$.

nules and less dense venation than C. rubescens. Laveine et al. (1977) suggested that this species might be the same as $C$. jongmansii and the pinnule morphotypes that characterise the two species are often found together. However, Laveine et al. (1977) provisionally maintained the distinction until a more complete analysis could be undertaken, a view with which we agree.

\section{Laveineopteris loshii (Brongniart) Cleal et al.}

Figure 7B, D

*1831 Nevropteris Loshi; Brongniart, p. 242,pl.72, fig. 1; pl. 73. "1953 Neuropteris heterophylla Brongniart. - Havlena (non Brongniart), pl. 3, fig. 2 (non fig. 1 - to Laveineopteris tenuifolia). 
$\$ 1990$ Laveineopteris loshii (Brongniart). - Cleal et al., p. 490.

『2009a Laveineopteris loshii (Brongniart) Cleal et al. - Opluštil et al., pl. 7, figs 7, 8 .

『2009b Laveineopteris loshii (Brongniart) Cleal et al. - Opluštil et al., fig. $8 \mathrm{~g}$.

`2007 Laveineopteris loshii (Brongniart) Cleal et al. Šimůnek, pl. 3, figs 2-8; pl. 5, fig. 6.

`2011 Laveineopteris loshii (Brongniart) Cleal et al. Šimůnek \& Cleal, pls 5-7.

『2014 Laveineopteris loshii (Brongniart) Cleal et al. - Opluštil et al., fig. 16a.

Remarks. - This species, often historically misidentified as Neuropteris heterophylla (Brongniart) Brongniart (as discussed by Laveine 1967), is extremely abundant in many floras from the Langsettian to Bolsovian of the paralic basins of Europe (Cleal \& Shute 1995, 2003). It is less widespread in the CWBB, occurring mainly in the Whetstone Horizon tuffs. Feistmantel (1876) recorded it from Břasy ("Bras") which is normally associated with an "Opuky" tuffaceous intercalation in the Upper Radnice Seam. However, Havlena (1953) expressed some doubt as to this record, as this species is more typically found in the lower Bělka) part of the Whetstone Horizon and only rarely in the roof shales of the Upper Radnice Seam.

\section{Laveineopteris tenuifolia (Schlotheim ex Sternberg) Cleal et al., nom. cons.}

Figure 9E

1820 Filicites tenuifolius; Schlotheim, p. 405, pl. 22, fig. 1. [nom. illeg.]

*1825 Neuropteris tenuifolia (Schlotheim); Sternberg, p. 17. [nom. cons.]

? $₫ 1874$ Cyclopteris orbicularis Brongniart. - Feistmantel, pl. 67, figs 2, 3 .

ॠ1953 Neuropteris tenuifolia (Schlotheim). - Havlena, pl. 3, figs 3-6; pl. 6, fig. 3; pl. 7, figs 3, 4.

"1953 Neuropteris heterophylla Brongniart. - Havlena (non Brongniart), pl. 3, fig. 1.

$\$ 1990$ Laveineopteris tenuifolia (Sternberg). - Cleal et al., p. 490.

ๆ2007 Laveineopteris tenuifolia (Sternberg) Cleal et al. Šimůnek, pl. 3, figs 9, 10; pl. 5, fig. 7.

ף2011 Laveineopteris tenuifolia (Schlotheim ex Sternberg) Cleal et al. - Šimůnek \& Cleal, pls $8-12$.
Remarks. - This species, which is differentiated from L. loshii mainly by having more elongate pinnules, is also widespread in the Langsettian to Bolsovian floras of the paralic coal basins, but in the CWBB, appears to be restricted to the roof shales of the Radnice Member. Ettingshausen (1854, p. 34) recorded Cyclopteris orbicularis Brongniart from the roof shales of the Radnice Seam (Mostiště locality), which may belong to this species.

\section{Laveineopteris bohemica (Ettingshausen) Šimůnek Figure 9B, C}

*1854 Neuropteris bohemica; Ettingshausen, p. 34, pl. 13, fig. 1.

^1854 Neuropteris rubescens Sternberg. - Ettingshausen (non Sternberg), pl. 14, figs 4, 5.

"1929 Neuropteris bohemica Ettingshausen. - Němejc, pl. 1, fig. 9; pl. 2.

ฯ1953 Neuropteris attenuata Lindley and Hutton. - Havlena (non Lindley \& Hutton), pl. 1, figs 1-5; pl. 2, figs 1-3.

ף2011 Laveineopteris bohemica (Ettingshausen) Šimůnek. Šimůnek \& Cleal, pls 13-15.

ๆ2013 Laveineopteris bohemica (Ettingshausen) Cleal et al. - Šimůnek \& Cleal, figs 1-3.

Remarks. - This species is similar to Laveineopteris rarinervis (Bunbury) Cleal et al. found abundantly in the upper Westphalian of the lowland basins of Western Europe and North America, but is distinguished by its thinner and less widely forking veins, and different epidermal structure (Šimůnek \& Cleal 2011). It is conspecific with the specimens named Neuropteris nicolausiana Gothan from Upper Silesia (Gothan 1913) and Neuropteris nikolausii Gothan from Saar-Lorraine (Bertrand 1930), and appears to be a species characteristic of more upland wetland habitats.

The attribution of the specimens from the Radnice Member figured by Ettingshausen (1854) as N. rubescens to L. bohemica is based on the comments by Němejc (1929, p. 5; see also Gothan 1913, p. 213 and Havlena 1953). Němejc (1929) also figured cyclopterids and possible ovules associated with this species. L. bohemica is relatively common in the Radnice Member of the CWBB.

\section{Laveineopteris lubnensis (Havlena) Šimůnek \& Cleal Figure 4D}

*1953 Neuropteris lubnensis; Havlena, p. 58, pl. 6, figs 1, 2.

$\$ 2011$ Laveineopteris lubnensis (Havlena). - Šimůnek \& Cleal, pls 16, 17.

Figure 7. Medullosalean frond fragments from the Kladno Formation, Central and Western Bohemian basins. • A - Macroneuropteris scheuchzeri (Hoffmann) Cleal et al. Tlustice, Na Štilci locality, Whetstone Horizon, National Museum Akc. No. p 1635. • B, D - Laveineopteris loshii (Brongniart) Cleal et al., Ovčín near Radnice, Whetstone Horizon. coll. West Bohemian Museum Pilsen. • C - Callipteridium rubescens (Presl ex Sternberg) Wagner ex Bashforth et al., Močidlec (Sauberg) locality, Žihle Basin, Nýřany Member, Asturian (coll. CGS, No. ZŠ 851). Scale bars: A, B = 1 cm; C, D = 5 mm. 

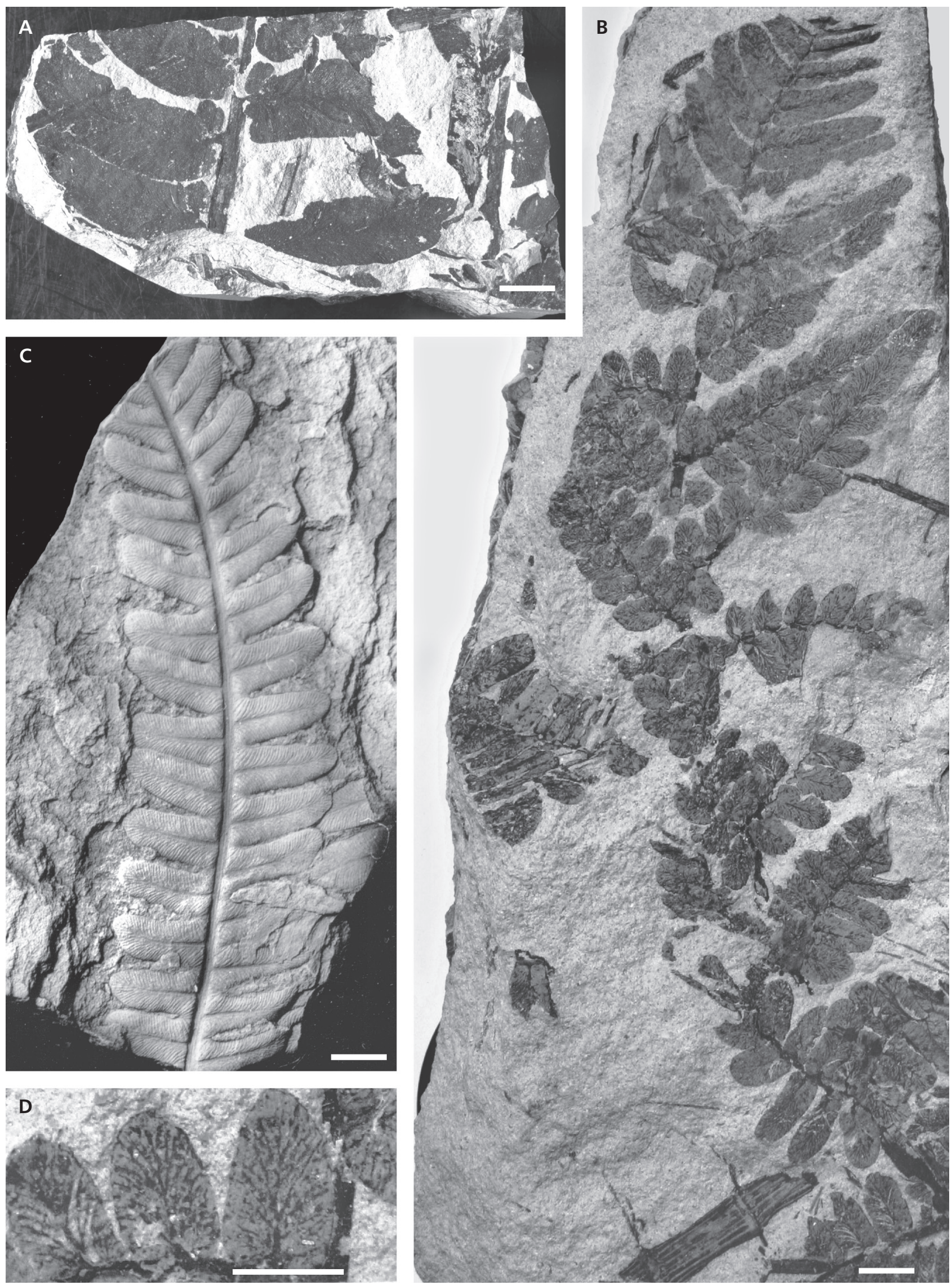
Remarks. - This species appears to be endemic to the tuffs and tuffites associated with the Lubná coals. Its attribution to Laveineopteris was based on the cuticles, which resemble those of $L$ loshii and L. tenuifolia described from both the CWBB (Šimůnek \& Cleal 2011) and elsewhere (Barthel 1962; Cleal \& Shute 1992, 1995, 2003, 2012).

\section{Laveineopteris hollandica (Stockmans) Cleal \& Shute Figure 6D}

*1933 Neuropteris hollandica; Stockmans, p. 31, pl. 10, fig. 1. 『1977 Neuropteris hollandica Stockmans. - Šetlík, pl. 3, fig. 1.

$\$ 1995$ Laveineopteris hollandica (Stockmans). - Cleal \& Shute, p. 20.

Remarks. - This species is similar to L. tenuifolia but has finer and more oblique veins. It is rare in the CWBB but Šetlík (1977, pl. 3, fig. 1) illustrated it from above the Upper Radnice Seam. It was also identified by R.H. Wagner (personal communication 2006) from the OvčínPř́ivětice excavation of the Bělka tuff.

\section{Palaeoweichselia defrancei (Brongniart) Potonié \& Gothan}

Figure $6 \mathrm{C}, \mathrm{F}$

*1834 Pecopteris defrancei; Brongniart, p. 325.

$\$ 1909$ Palaeoweichselia defrancei (Brongniart). - Potonié \& Gothan in Potonié, part 116.

Remarks. - There are no published reports of this species from the CWBB, but there are eight specimens in the National Museum (Prague) from the Whetstone Horizon (Bělka layer) at Malé Př́lepy, which are very similar. In the absence of previous records from these coal basins, we give the following brief description.

The most complete specimen is part of an antepenultimate pinna with main rachis $7 \mathrm{~mm}$ wide, bearing pairs of subopposite penultimate rachises at $c .70 \mathrm{~mm}$ intervals. Also present are shorter intercalated monopinnate segments spaced $c .18 \mathrm{~mm}$ apart, up to $c .35 \mathrm{~mm}$ long with oppositely arranged subtriangular, broadly attached pinnules up to $9 \mathrm{~mm}$ long. Penultimate rachises $4-6 \mathrm{~mm}$ wide bearing alternately to suboppositely-arranged ultimate rachises at $15-20 \mathrm{~mm}$ intervals. Ultimate rachises obtusely attached $\left(70-90^{\circ}\right)$, mostly straight but in some cases they curve in their proximal part.

Ultimate axes bear alternately or suboppositely arranged lateral pinnules at intervals of $3-4 \mathrm{~mm}$, as well as an elongate, tapered apical pinnules. Pinnule attachment varies from $70^{\circ}$ to $90^{\circ}$, tending to become more acute in the distal part of pinna. Pinnules linguaeform to subtriangular with round apex, broadly attached to rachis and adjacent pinnules often narrowly confluent. Basally decurrent mid- vein runs along $2 / 3-3 / 4$ the pinnule length, reducing to $1 / 4$ pinnule length in most distal part of pinna. Broadly arched lateral veins, sometimes somewhat flexuous (although it is difficult to be sure this is not taphonomic) but no sign of pseudo-anastomosing, twice occasionally three-times forked, meeting pinnules margin at $c .60^{\circ}$.

The specimens compare closely with examples from Saar-Lorraine, the type area for this species (e.g. Bertrand 1932, pls 48-53; Laveine 1989, pls 31, 32); they all have somewhat tapered, often oblique pinnules and flexuous veins. Although it is more characteristic of somewhat younger (late Bolsovian to early Asturian) floras in SaarLorraine (Bertrand 1932) it also occasionally ranges into lower Bolsovian strata (Laveine 1989, Laveine \& Goubet 1995) and so overlaps with its occurrence in the Radnice Member. According to Laveine et al. (1977) and Laveine \& Goubet (1995) this species may be related to Callipteridium and so it is assigned here to the Cyclopteridaceae. In the CWBB, this species is practically known only from the Whetstone Horizon (Bělka) of the Malé Přilepy relic.

\section{Family Parispermaceae}

Remarks. - This fossil-family comprises fronds with a pseudo-pinnate architecture sensu Laveine (1997) that lacks a major proximal bifurcation and has intercalated pinnules on all orders of rachises. The pinnae are also characterised by being paripinnate (i.e. terminated by a pair of terminal pinnules) rather than imparipinnate as with the other medullosalean fronds.

\section{Linopteris neuropteroides (Gutbier) Potonié}

Figure 9G

*1855 Dictyopteris neuropteroides; Gutbier in Geinitz, p. 23. $\$ 1899$ Linopteris neuropteroides (Gutbier). - Potonié, p. 154.

†2007 Linopteris neuropteroides Gutbier. - Šimůnek, pl. 4, figs 10-13; pl. 5, figs 10, 11.

ๆ2011 Linopteris neuropteroides Gutbier. - Bashforth et al., pl. 2 , fig. 8 .

Remarks. - This widespread species is characterised by relatively large, often somewhat subfalcate pinnules and dense, elongate veins meshes. Two subspecific taxa (usually designated as forma) can be recognised: Linopteris neuropteroides (Gutbier) Potonié forma neuropteroides (referred to by Potonié 1904 as forma major) with larger pinnules and Linopteris neuropteroides forma minor Potonié, 1904 with consistently smaller pinnules. There are still some nomenclatural problems surrounding these taxa but for this study we continue to use these forma names. The forma neuropteroides occurs in the Radnice and Nýřany members, but both formas occur in the Nýřany Member. 

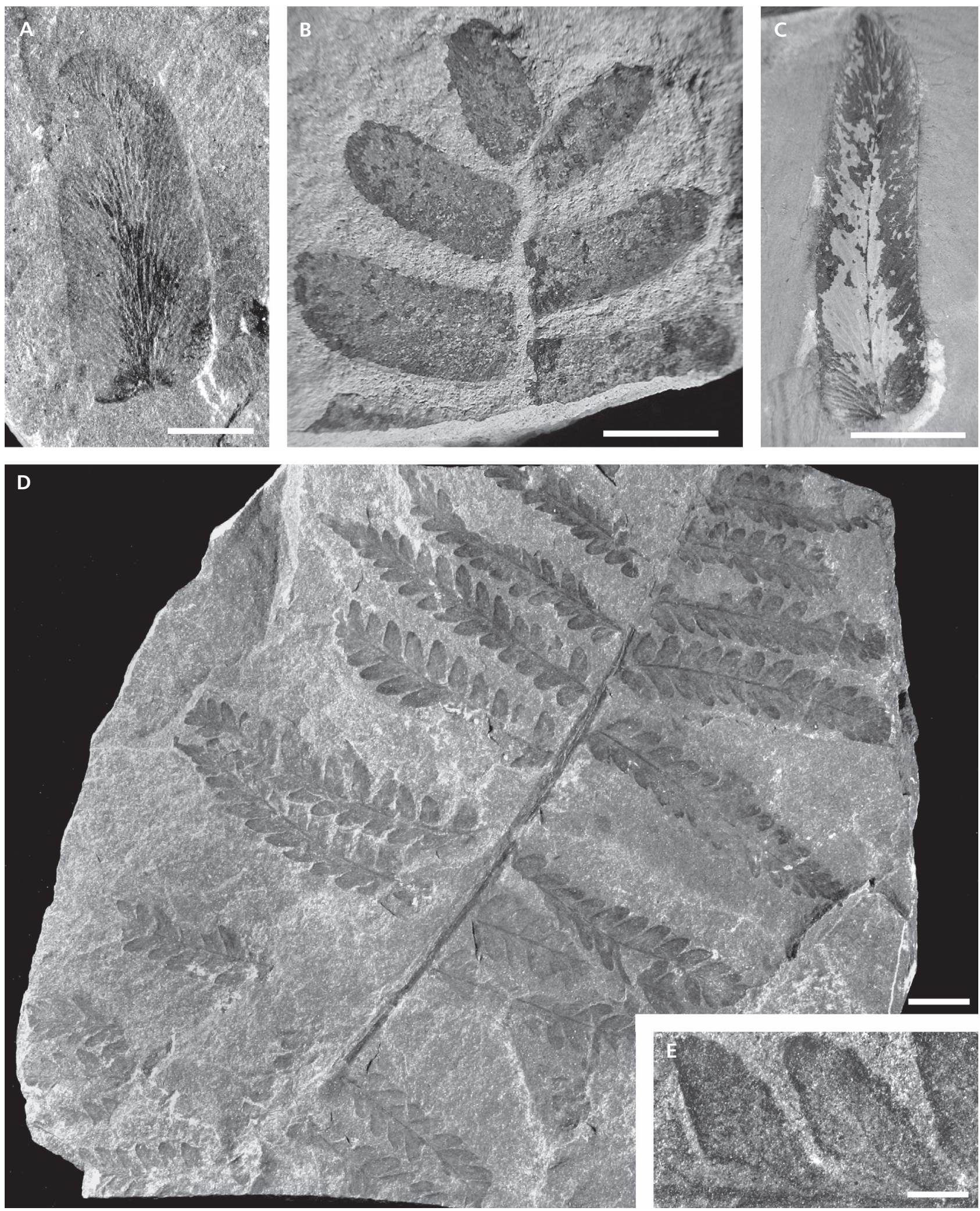

Figure 8. Medullosalean frond fragments from the Kladno Formation, Central and Western Bohemian basins. • A - Linopteris obliqua (Bunbury) Zeiller, Nýřany Member, Skvrňany lokality, Šn 13 borehole, wedge 309.2-309.5 m, Plzeň Basin, No. ZŠ 849. • B - Paripteris linguaefolia (Bertrand) Josten, Radnice Member, Lubná group of coals, Rakovník locality, Rako mine. Kladno-Rakovník Basin, NMP No. E 7635. • C - "Mixoneura" muensterifolia Němejc, Pejpina u Hudlic locality, Hýskov relic, Radnice Member, No. E 6011. • D, E - Odontopteris reichiana Gutbier. Nýřany Member, Mines between Blatnice and Doubrava, photo: Němejc (1949, pl. 2, fig. 5) Nat. Muz. E 6028. Scale bars: A= 5 mm; B-D = $1 \mathrm{~cm} ; \mathrm{E}=2 \mathrm{~mm}$. 


\section{Linopteris obliqua (Bunbury) Zeiller}

Figure 8A

*1847 Dictyopteris obliqua; Bunbury, p. 427.

$\$ 1899$ Linopteris obliqua (Bunbury). - Zeiller, p. 46.

ๆ2011 Linopteris obliqua (Bunbury) Zeiller. - Bashforth et al., pl. 2, fig. 12.

`2011 Linopteris palentina Wagner. - Bashforth et al., pl. 2, fig. 11.

Remarks. - This differs from L. neuropteroides by having usually smaller, more linguaeform pinnules and more isodiametric veins meshes. It typically occurs in uppermost Bolsovian to Cantabrian floras in Europe. Bashforth et al. (2011) figured two pinnules as L. obliqua and L. palentina. The pinnule identified as L. obliqua is very similar to specimens from its type area documented by Zodrow et al. (2007; see also Zodrow \& McCandlish 1978). The other specimen has somewhat finer vein meshes but the pinnule size is rather smaller than is typical for L. palentina (Wagner 1964a, pl. 1, fig. 7; Wagner et al. 1983, pl. 12, figs 2-4). Since L. palentina has not been reported from outside of Iberia and, given the infraspecific variation in pinnule shape and venation of these species, we have assigned both Czech specimens to the same species, which we call L. obliqua. This species is not very common in the Nýrany Member of the CWBB.

\section{Linopteris weigelii (Sterzel) Daber}

Figure 9F

*1881 Dictyopteris weigeli; Sterzel, p. 76.

\$1955 Linopteris weigeli (Sterzel). - Daber, p. 37.

\1977 Linopteris weigeli (Sterzel). - Šetlík, pl. 6, fig. 2.

2009 Linopteris weigeli (Sterzel). - Kahlert \& Schultka in Hoth et al., p. 80, pl. 4, fig. 7 (holotype).

Remarks. - This species is distinctive because of the dimensions of its pinnules. The vein meshes are larger than in L. neuropteroides but of similar elongate aspect. It is a very rare species in the Nýrany Member of the CWBB.

\section{Paripteris linguaefolia (Bertrand) Josten}

Figure 8B
*1930 Neuropteris linguaefolia; Bertrand, p. 31.

\1953 Neuropteris linguaefolia Bertrand. - Havlena, pl. 6, figs 4, 5.

\$1966 Paripteris linguaefolia (Bertrand). - Josten, p. 573.

ף2007 Paripteris linguaefolia (Bertrand) Laveine. - Šimůnek, pl. 4, fig. 9; pl. 5, fig. 9.

Remarks. - Pinnules of this species tend to have linguaeform pinnules and only a weakly developed midvein, in contrast to $P$. gigantea (Sternberg) Gothan pinnules which tend to be more falcate and a prominent midvein. Havlena (1953, p. 50) recorded $P$. gigantea from the Kladno Formation, but all of his figured specimens were from the Lower Silesia region (from where Sternberg's type originated). This species is normally associated with Langsettian and lower Duckmantian floras, although it does rarely range up into the upper Duckmantian (e.g. Laveine 1967). However, since all of the recorded localities for this species in the Kladno Formation also yielded typical examples of $P$. linguaefolia, it seems likely that Havlena's records of $P$. gigantea represent variation in $P$. linguaefolia.

Family uncertain

Remarks. - The frond architecture of these species is unknown and, since the pinnae are morphologically quite different from other medullosalean species, it is impossible at this time to place them in a fossil-family.

\section{Havlenaea coriacea (Ettingshausen) Šimůnek \& Cleal} Figure 5C

*1852 Neuropteris coriacea; Ettingshausen, pp. 9, 10, pl. 2, fig. 1.

๑1876 Neuropteris acutifolia Brongniart. - Feistmantel, pl. 66, fig. 4.

\1949 Mixoneura praeovata; Němejc, text-fig. 2; pl. 4, figs $1-7$.

ף1949 Mixoneura grandifolia; Němejc, text-figs 3, 4.

†2007 Neuropteris praeovata (Němejc) Cleal \& Shute. Šimůnek, pl. 1, figs 1, 7; pl. 3, figs 11, 12; pl. 4, figs 1, 2.

ף2007 Mixoneura grandifolia Němejc. - Šimůnek, pl. 1, fig. 4.

"2011 Havlenaea praeovata (Němejc). - Šimůnek \& Cleal, pls $1,2$.

Figure 9. Medullosalean frond fragments from the Kladno Formation, Central and Western Bohemian basins. • A - Callipteridium armasii (Zeiller) Wagner, Nýřany Member, Radčice locality, Plzeň Basin, (Šimůnek 2008, fig. 16/4) CGS, No. ZŠ 320. B , C - Laveineopteris bohemica (Ettingshausen) Šimůnek; B - Doubrava-Blatnice locality, Plzeň Basin, No. F 2051 (West Bohemian Museum, Pilsen); C - Filip II Quarry, Lubná near Rakovník locality (CGU ZŠ 429). • D - Laveineopteris lubnensis (Havlena) Šimůnek \& Cleal, Radnice Member, Lubná near Rakovník locality, Filip II Quarry (CGU ZŠ 431). E - Laveineopteris tenuifolia (Schlotheim ex Sternberg) Cleal et al., nom. cons., Radnice Member, Motyčín near Kladno locality, No. E 1343. • F - Linopteris weigelii (Sterzel) Daber, Nýřany Member, Koštice locality, Ko 1 borehole, 892-892.8 m, Kladno-Rakovník Basin, No. JŠ 167. • G - Linopteris neuropteroides (Gutbier) Potonié forma neuropteroides, Křimice locality, Km 11 borehole, 260.4-261.4 m, Nýřany Member, No. ZŠ 847. • H - Havlenaea stradonitzensis (Andrä) Šimůnek \& Cleal, Radnice Member, Strádonice (NMP E 3794 ). All scale bars $=5 \mathrm{~mm}$. 
Zbyněk Šimůnek \& Christopher J. Cleal • Westphalian-earliest Stephanian medullosalean and allied plant fossils from Czech Republic
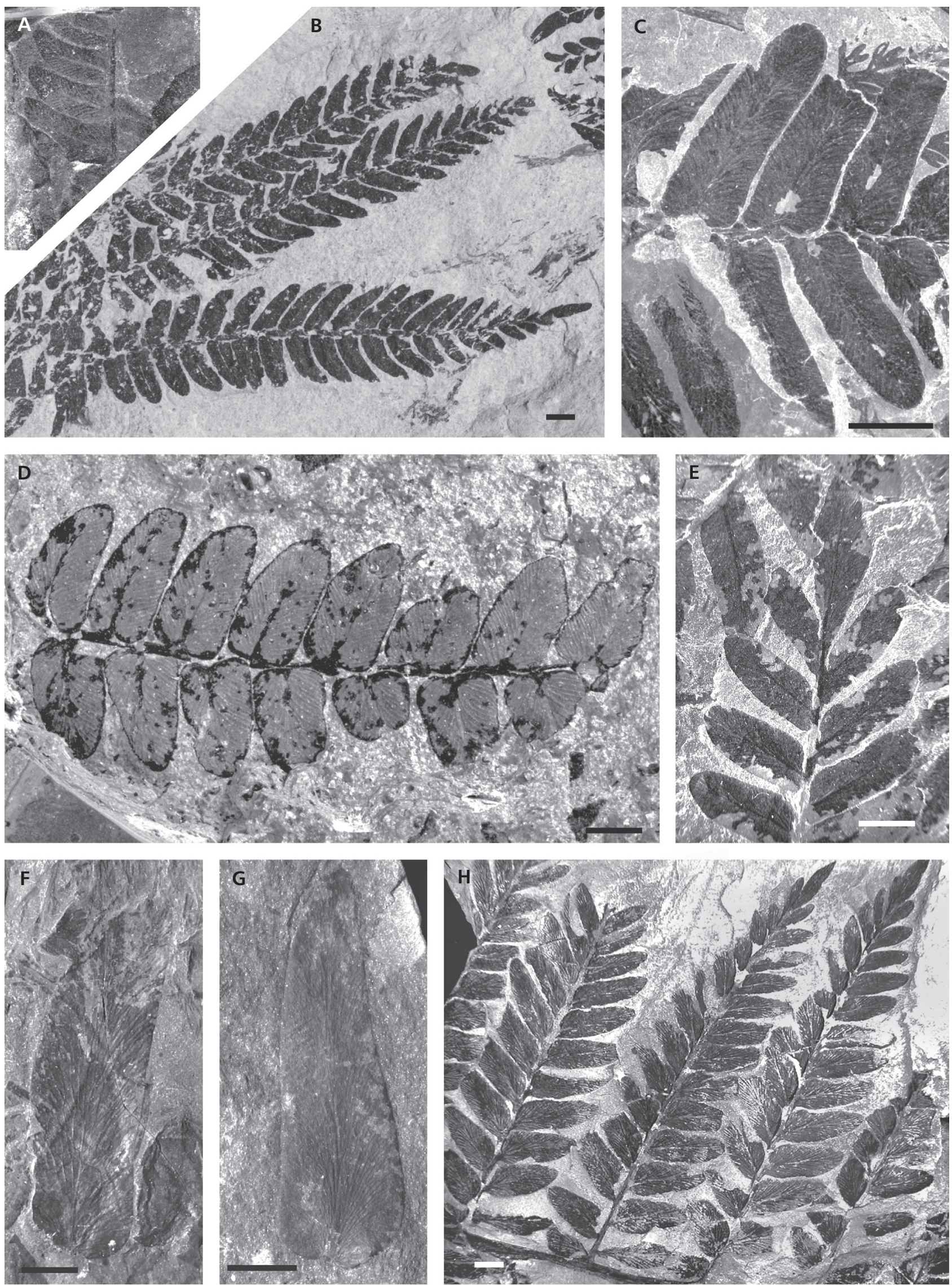

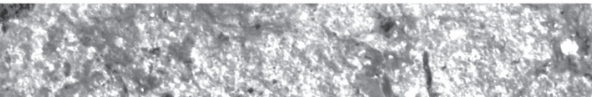

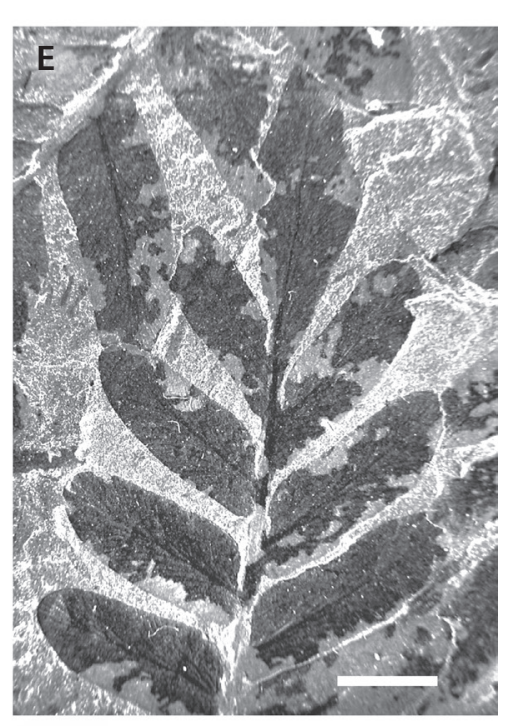

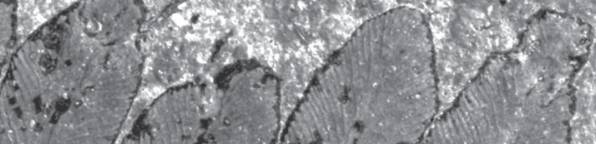

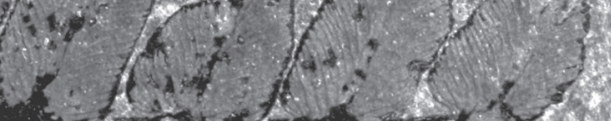

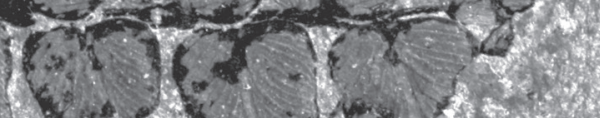
3.t.

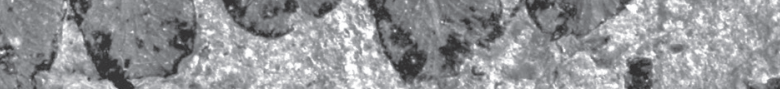

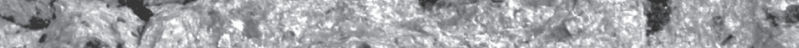

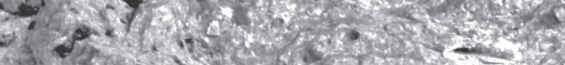

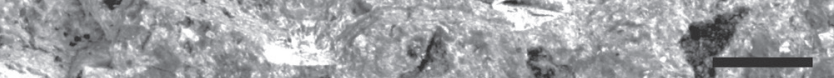
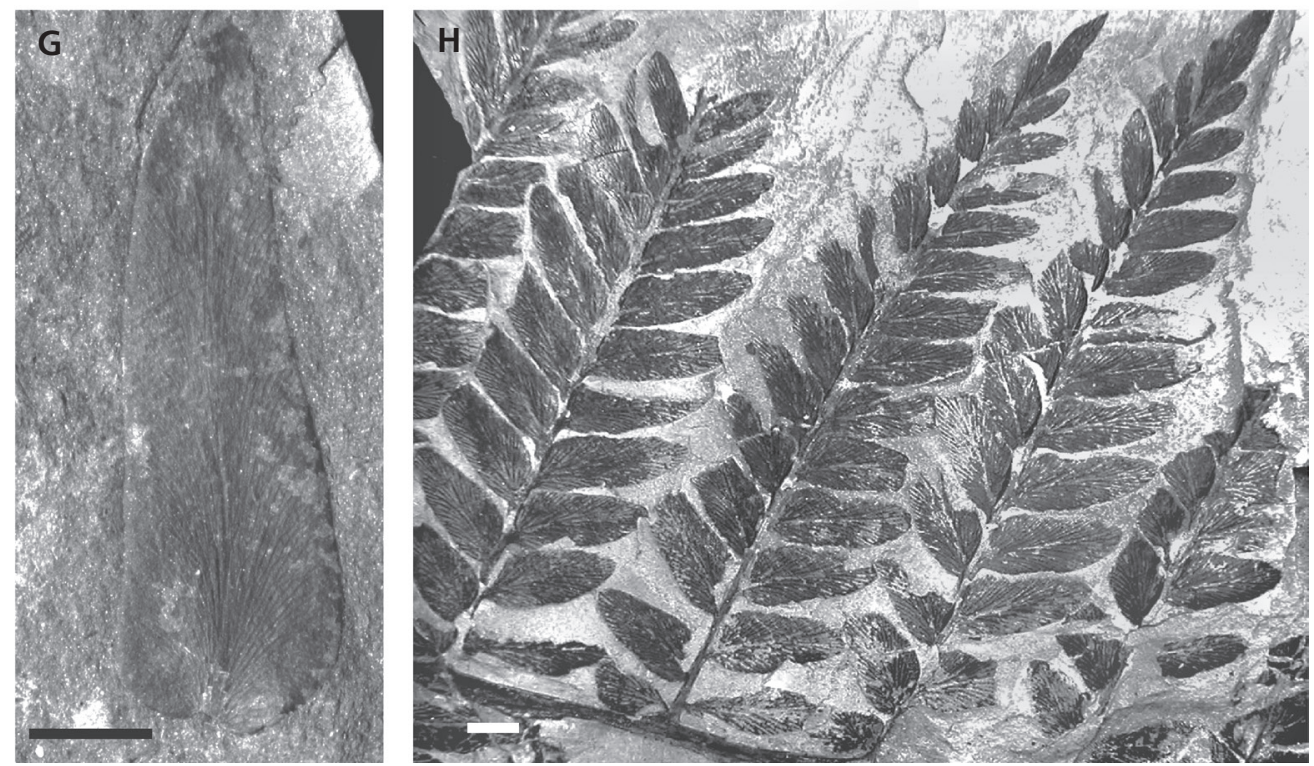
\$2016 Havlenaea coriacea (Ettingshausen). - Šimůnek \& Cleal, pl. 1.

Remarks. - The taxonomy of this species has been discussed in most detail by Šimůnek \& Cleal $(2011,2016)$. Pinnule morphology is highly variable but the different forms were shown to grade into each other, and all have similar epidermal structures. Němejc (1930) recorded but did not figure specimens from Stradonice as Neuropteris ovata Hoffmann, but on the specimen labels he wrote that they were not typical and rather older stratigraphically than the types of that species. He later made them the types of a new species, N. praeovata Němejc, 1949, but he was evidently unaware that the type of $N$. coriacea Ettingshausen, 1852 also belongs to this species and so the latter name must take precedence (see Šimůnek \& Cleal 2016 for further details).

Havlena (1953, p. 70) suggested that the specimen figured by Feistmantel (1876) as $N$. acutifolia was more correctly assignable to "M. praeovata" (三H. coriacea). However, the specimens figured by Havlena (1953, pl. 8, figs 1,2 ) as Neuropteris coriacea are in fact a Mariopteris, as hinted at by Havlena.

\section{Havlenaea stradonitzensis (Andrä) Šimůnek \& Cleal Figure 9H}

ॠ1864 Odontopteris sp. - Andrée, pl. 4, fig. 4a.

\1876 Odontopteris reichiana Gutbier. - Feistmantel (non Gutbier), pl. 67, figs 4, 5.

*1879 Aspidites stradonitzensis; Andrä, p. 104.

\1949 Odontopteris stradonicensis (Andrä). - Němejc, pl. 1, figs $1-8$.

『1954 Neuropteris stradonicensis (Andrä). - Gothan, pl. 4, fig. 3.

`2007 'Odontopteris' stradonicensis (Andrä) Němejc. Šimůnek, pl. 1, fig. 2; pl. 4, figs 3, 4.

\$2011 Havlenaea stradonitzensis (Andrä). - Šimůnek \& Cleal, pls 3, 4.

Remarks. - This species is similar to $H$. coriacea but has more odontopteroid-looking pinnules. The specimens figured by Feistmantel (1876) as O. reichiana originated from the Whetstone Horizon from where that species is unknown. They compare closely with specimens from the type locality for H. stradonicensis, such as those figured by Šimůnek \& Cleal (2011). This species is common in the Whetstone Horizon (Brousek) of the Stradonice locality, Hýskov relic.

\section{"Mixoneura" muensterifolia Němejc}

Figure 8C

\$1949 Mixoneura muensterifolia; Němejc, p. 15, text-fig. 1; pl. 3, figs 10-14.
†2007 Mixoneura muensterifolia Němejc. - Šimůnek, pl. 1, fig. 4.

"2011 “Mixoneura" muensterifolia Němejc. - Šimůnek \& Cleal, pl. 20.

Remarks. - Němejc (1949) assigned this species to Mixoneura sensu Bertrand (1930), which was intended for species intermediate between Neuropteris Brongniart and Odontopteris Brongniart. Current views of this fossil-genus are rather different (e.g. Wagner 1964b, Wagner \& Castro 1998, Laveine \& Legrand 2019). However, there is no obvious existing fossil-genus to which this species could be assigned, and it is insufficiently well preserved to make the basis of a new genus. We have therefore retained the provisional nomenclature suggested by Šimůnek \& Cleal (2011). This species occurs relatively rarely in the Whetstone Horizon (Brousek) of the Stradonice locality, Hýskov relic.

\section{Palaeofloristic analyses}

For the P. linguaefolia Zone analysis, data from the different facies of the Radnice Member (as summarised above) were separated and then incorporated into the Cleal (2008b) dataset (the basins included in the Cleal 2008 b analysis are shown in Fig. 10). It is evident from the dataset (Tab. 1) that the floras from all three roof shales (from the Plzeň, Upper Radnice and Lubná seams) were broadly similar and were therefore combined. The species listed in Cleal (2008b) for the Intra-Sudetic Basin (upper Prkenný Důl-Žd'árky and Petrovice members of the Žaclér̆ Formation) were also modified following the revision by Opluštil et al. (2017); and those from northern Turkey based on some of the records in Opluštil et al. (2018). The Donets data were excluded as, although Boyarina (2016) has recently published a biostratigraphical review, there has been no comprehensive taxonomic treatment of the medullosaleans since Novik (1952).

The resulting cluster and ordination analyses for the $P$. linguaefolia Zone medullosaleans are shown in Fig. 11. This reveals an essentially three-fold structure, representing the floras referred to by Cleal (2008b) as the Rhine Palaeoprovince and Silesia Palaeoprovince, and a loose cluster of the intramontane basin floras of the CWBB and Saar-Lorraine. Unlike in the Cleal (2008b) model, the CWBB floras are now clustering rather closer to those of Saar-Lorraine, except for the Lubná tuffs and tuffites floras. If the latter data are removed from the model (also the singleton Intra-Sudetic Basin flora), a PERMANOVA test based on the Raup-Crick coefficients confirmed that the resulting three groups are statistically significantly different $\left(\mathrm{F}=69.3, \mathrm{p}_{\text {(same) }} \leq 0.01 \%\right)$.

Unlike in the Cleal (2008b) analysis, a single, combined analysis was performed for the Crenulopteris 
Table 1. Distribution of medullosalean fossil-species in the Radnice Member, Central and Western Bohemian basins. Taphonomy: Para. parautochthonous; Auto. - autochthonous; Mixed - mixed autochtonous, parautochthonous and allochtonous. Symbols: X - rare; (?) - not sure; $\bullet-$ common; •* - common in one locality.

\begin{tabular}{|c|c|c|c|c|c|c|c|c|}
\hline & \multirow{3}{*}{$\begin{array}{c}\text { Plzeň coal } \\
\text { group } \\
\text { (Para.) }\end{array}$} & \multicolumn{4}{|c|}{ Radnice coal group } & \multicolumn{3}{|c|}{ Lubná coal group } \\
\hline & & \multicolumn{2}{|c|}{ Whetstone Horizon } & \multicolumn{2}{|c|}{ Upper Radnice Seam } & \multirow{2}{*}{$\begin{array}{l}\text { Z-tuff } \\
\text { (Auto.) }\end{array}$} & \multirow{2}{*}{$\begin{array}{c}\text { Laminated } \\
\text { tuffites } \\
\text { (Mixed) }\end{array}$} & \multirow{2}{*}{$\begin{array}{c}\text { Mudstones } \\
\text { (Para.) }\end{array}$} \\
\hline & & $\begin{array}{l}\text { Bělka } \\
\text { (Auto.) }\end{array}$ & $\begin{array}{l}\text { Brousek } \\
\text { (Mixed) }\end{array}$ & $\begin{array}{l}\text { "Opuky" } \\
\text { (Mixed) }\end{array}$ & $\begin{array}{c}\text { "Mydláky" } \\
\text { (Para.) }\end{array}$ & & & \\
\hline Alethopteris cf. pseudograndinioides & & & & & & & $\mathrm{X}$ & \\
\hline Alethopteris distantinervosa & $\mathrm{X}$ & $\bullet$ & $(?)$ & $\mathrm{X}$ & $\mathrm{X}$ & & & $\mathrm{X}$ \\
\hline Alethopteris lonchitica & $(?)$ & $\mathrm{X}$ & $(?)$ & $\mathrm{X}$ & $\mathrm{X}$ & $\mathrm{X}$ & $?$ & $\mathrm{X}$ \\
\hline Alethopteris nemejcii & $\bullet$ & & & & $\bullet$ & & & \\
\hline Alethopteris cf. serlii & & & $\mathrm{X}$ & & $\bullet$ & & & \\
\hline Havlenaea coriacea & & & $\bullet$ & $\mathrm{X}$ & & & & \\
\hline Havlenaea stradonitzensis & & & $\bullet$ & & & & & \\
\hline Laveineopteris bohemica & $\bullet$ & $\mathrm{X}$ & $\mathrm{X}$ & $\mathrm{X}$ & $\bullet$ & & & $\bullet$ \\
\hline Laveineopteris hollandica & & $\mathrm{X}$ & & & $\mathrm{X}$ & & & \\
\hline Laveineopteris loshii & $\mathrm{X}$ & $\bullet$ & & & $\mathrm{X}$ & & & \\
\hline Laveineopteris lubnensis & & & & & & $\bullet *$ & $\bullet$ & \\
\hline Laveineopteris tenuifolia & $\bullet$ & & & & $\bullet$ & & & $\bullet$ \\
\hline $\begin{array}{l}\text { Linopteris neuropteroides } \mathrm{f} . \\
\text { neuropteroides }\end{array}$ & $\mathrm{X}$ & & & $\mathrm{X}$ & $\bullet$ & & & $\bullet$ \\
\hline Lonchopteris rugosa & & & $\bullet$ & & & & & \\
\hline Macroneuropteris scheuchzeri & $\bullet$ & $\bullet$ & $\bullet$ & $\bullet$ & $\mathrm{X}$ & $\mathrm{X}$ & $\mathrm{X}$ & \\
\hline Mixoneura' muensterifolia & $\mathrm{X}$ & & $\mathrm{X}$ & & & & & \\
\hline Palaeoweichselia defrancei & & $\mathrm{X}$ & & & & & & \\
\hline Paripteris linguaefolia & $\mathrm{X}$ & & & & $\mathrm{X}$ & & $\mathrm{X}$ & $\bullet$ \\
\hline
\end{tabular}

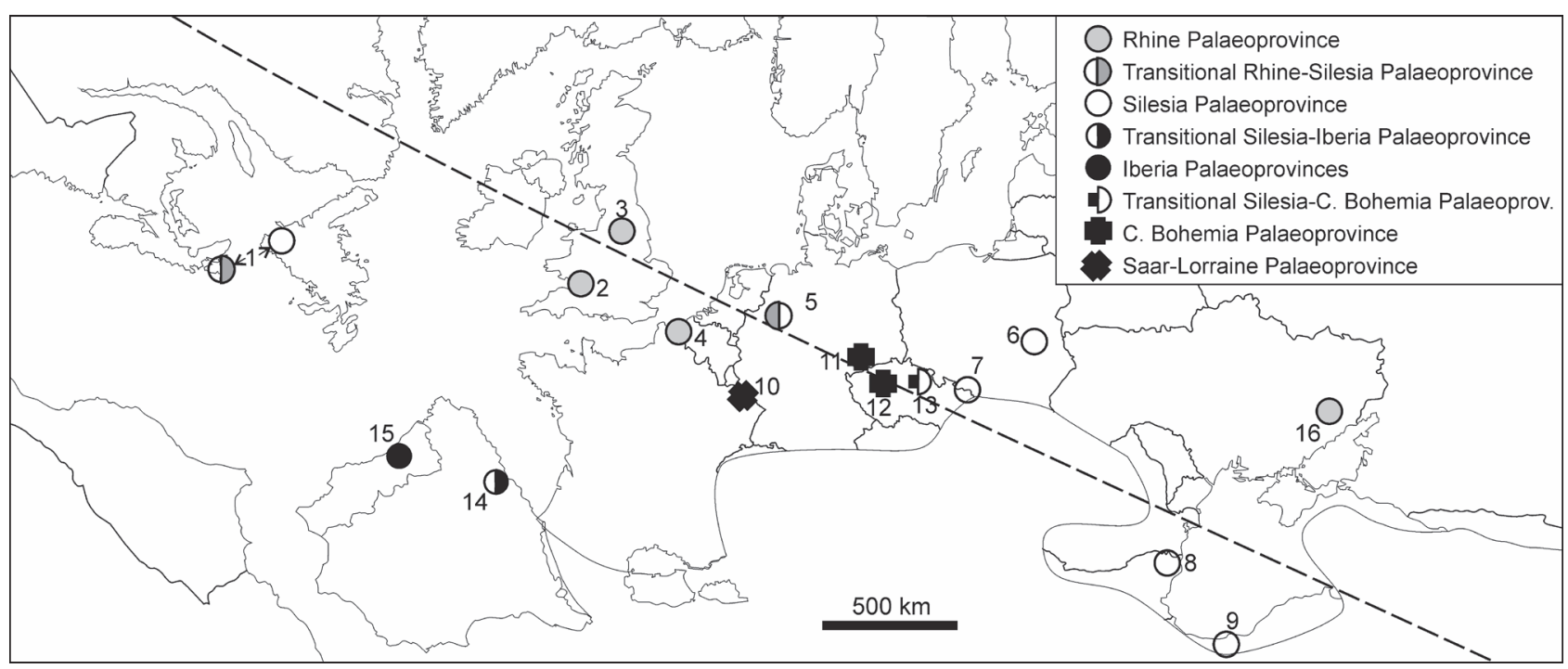

Figure 10. Location of 16 coal basins dealt with in this study, plotted on a late Carboniferous palinspastic map. Legend: 1 - Canadian Maritimes; 2 - SW Britain; 3 - Pennines; 4 - Franco-Belgian Basin; 5 - NW Germany; 6 - Lublin; 7 - Upper Silesia; 8 - Dobrudzha; 9 - N Turkey; 10 - SaarLorraine; 11 - Zwickau; 12 - CWBB; 13 - Intra-sudetic Basin; 14 - NW Spain; 15 - Portugal; 16 - Donets. The dashed line approximates to the position of the palaeoequator in late Carboniferous times. Reproduced from Cleal (2008b, fig. 2). 


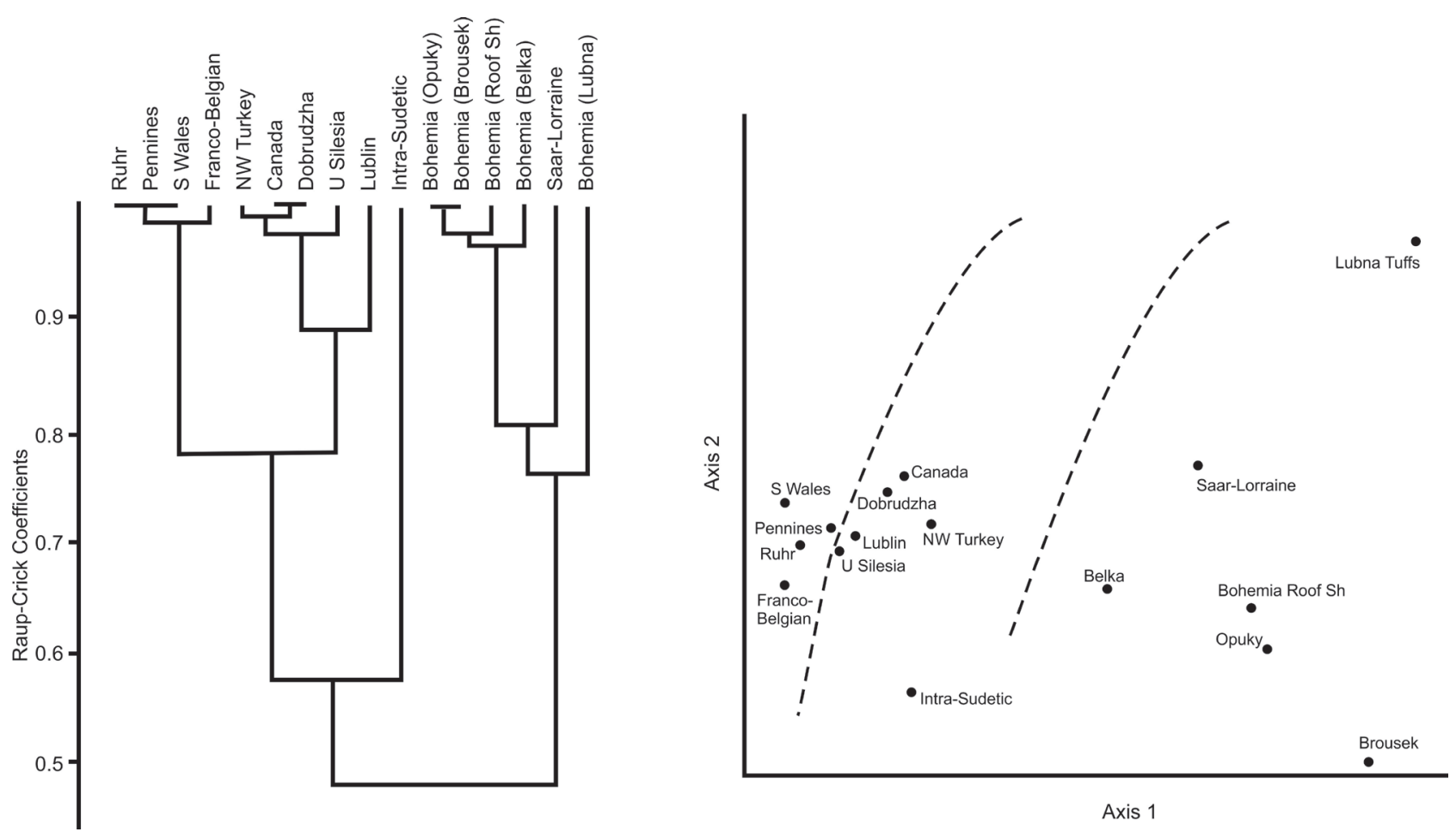

Figure 11. Palaeofloristic analyses of the P. linguaefolia Zone floras with the new data for the Radnice Member. The areas demarcated on the DCA ordination reflect the major groupings revealed by the cluster analysis. See text for details of methods used.

acadica and Odontopteris cantabrica zones. Although the zonal boundary is biostratigraphically important as it indicates the Westphalian-Stephanian stage boundary (Cleal et al. 2003), there are not major differences in the medullosaleans present. Consequently, the species listed for the Nýřany Member are treated as a whole. Data for the Intra-Sudetic Basin were modified following Opluštil et al. (2017). As with the Radnice Member, there is a clear separation of two phytochoria for the lowland paralic areas, and a loose cluster of the central European intramontane basins (Fig. 12). The situation of the Iberian floras (NW Spain and Portugal) remains uncertain and clearly requires further investigation.

\section{Discussion}

\section{Radnice Member}

The underlying structure of the revised $P$. linguaefolia Zone palaeofloristic model (Fig. 10) is similar to that in Cleal (2008b), with two phytochoria being differentiated on the foreland areas: the Ruhr Palaeoprovince (the Pennines, South Wales, Franco-Belgian and Ruhr basins) and the Silesia Palaeoprovince (Upper Silesia, Lublin, Dobrudzha, Northern Turkey and Canada). However, there is now a much closer grouping of most of the intramontane
CWBB and Saar-Lorraine floras. In the Cleal (2008b) analysis CWBB and Saar-Lorraine were assigned to their own separate phytochoria (palaeoprovinces) but here we will group them together as the Bohemia-Saar-Lorraine Palaeoprovince.

The distinctive aspect of the Bohemia-Saar-Lorraine Palaeoprovince in the middle Westphalian is largely due to the absence of many of the abundant and characteristic species found in the lowland basins such as Laveineopteris rarinervis, Neuropteris obliqua (and related forms as discussed by Josten 1962), Alethopteris urophylla and Alethopteris decurrens. There are in contrast relatively few species that unite the floras of the intramontane basins. Exceptions are Laveineopteris bohemica and Palaeoweichselia defrancei, but even here there are also links with the paralic basin floras: L. bohemica also occurs in Upper Silesia and northern Turkey, on the margins of the foreland basin, and $P$. defrancei has been reported as occurring rarely in Nord-Pas-de-Calais. These connections with marginal parts of the Variscan foreland may have provided the corridors via which these species could disperse between these intramontane basins.

In the paralic basins, the roof shale floras representing mainly the vegetation of clastic substrate habitats tend to be rather different from the vegetation of the peat substrate habitats represented in the coals (Gastaldo et al. 1995). In contrast, the vegetation preserved in the Radnice Member 

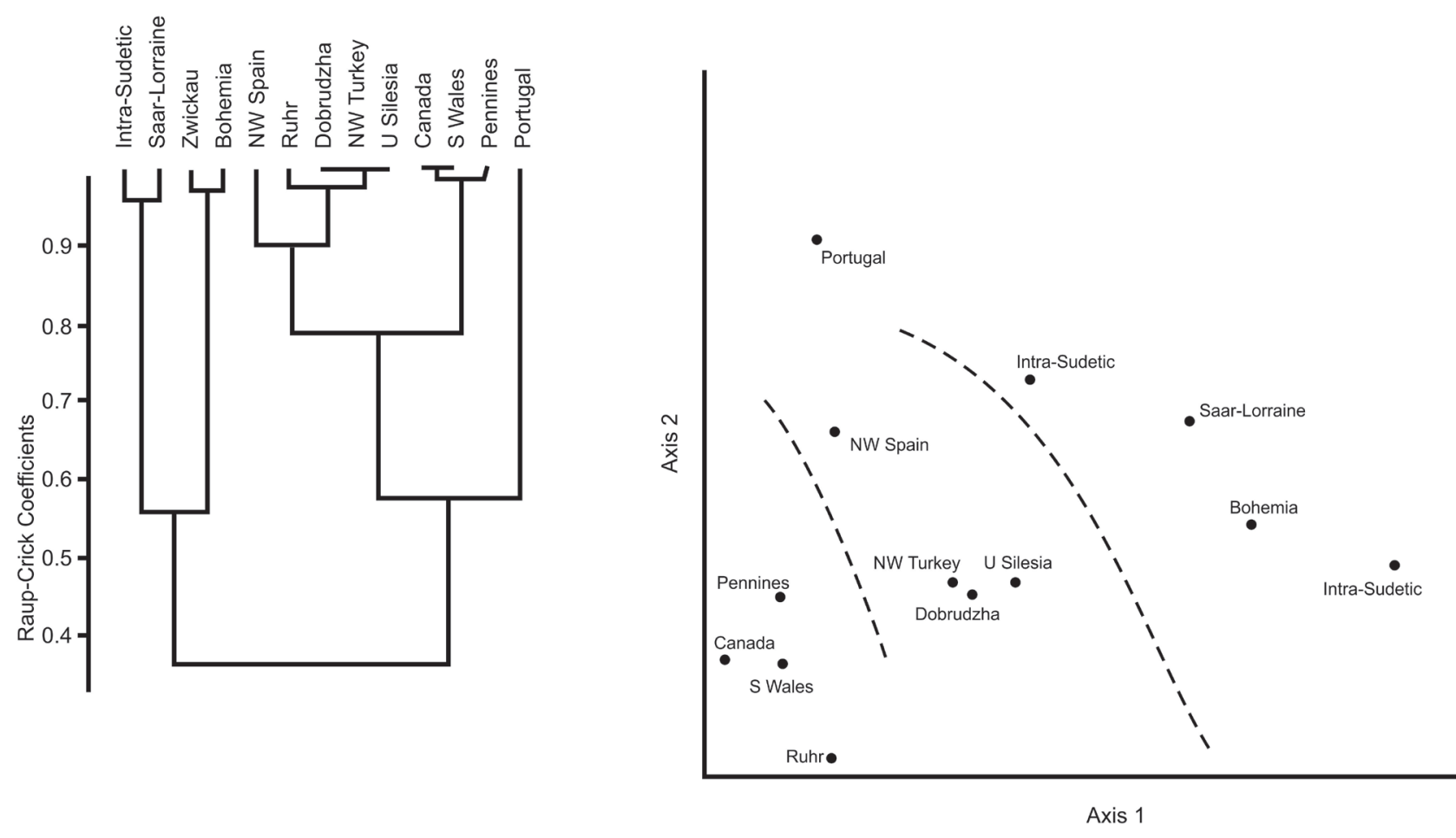

Figure 12. Palaeofloristic analyses of the $C$. acadica and $O$. cantabrica zones floras with the new data for the Nýřany Member. The areas demarcated on the DCA ordination reflect the major groupings revealed by the cluster analysis. See text for details of methods used.

roof shales does not seem to differ markedly from the peat substrate vegetation such as found in the Bělka tuff (e.g. Opluštil et al. 2007, 2009a, b, 2014). The explanation for this difference from what is seen in the paralic basins is unclear as the palaeoecology of the Radnice Member roof shale floras is has not been investigated in detail. Perhaps the narrower palaeogeomorphology of this intramontane basin (Opluštil 2005) constrained the drainage system from developing extensive floodplains with clastic substrate habitats, and the roof shales are preserving allochthonous remains of plants that were growing on localised peat substrates elsewhere in the basin, or perhaps on betterdrained fan delta systems. This is evidently a subject that requires further investigation.

The distinction of the floras from the Lubná tuffs and tuffite appears to be mainly due to the presence of the endemic Laveineopteris lubnensis and the stratigraphically early occurrence of Alethopteris pseudograndinioides, and the absence of taxa found abundantly in the other the CWBB floras such as Havlenaea spp., Laveineopteris bohemica, L. tenuifolia, Alethopteris nemejcii and Linopteris neuropteroides. However, these tuffs and tuffites are known from only a very restricted number of localities, which clearly merit further investigation.

Opluštil \& Cleal (2007) reported what appeared to be a significantly higher floral diversity in the Radnice Member compared with other adpression floras of simi- lar age in Variscan Euramerica. However, the data presented here suggests that this was due to combining taxonomic lists from different facies and therefore habitats in the CWBB data and that, at least for the Medullosales diversities within habitats were not significantly higher.

\section{Nýřany Member}

The study also confirms the clear differences suggested by Cleal (2008b) between the Nýrany Member floras and those of contemporaneous deposits in the paralic basins such as Britain and the Canadian Maritimes (Fig. 11). Again, however, this is mainly due to the absence from the intramontane floras of a number of species regarded as characteristic of the lowland floras such as Laveineopteris rarinervis, Alethopteris pseudograndinioides, Alethopteris ambigua and Alethopteris serlii. There are a few species recorded from the CWBB but not from similar-aged strata in the lowland basins (e.g. Alethopteris kettneri, Linopteris weigelii, Odontopteris reichiana) but these tend to be relatively rare (Tab. 2). Also as with the Cleal (2008b) analysis, the Nýrany Member floras broadly group with those of the contemporaneous Heiligenwald Formation floras of Saar-Lorraine, the other major intramontane basin in Europe at this time. 
Table 2. Distribution of medullosalean fossil-species in the Nýřany Member, Central and Western Bohemian basins. Symbols: X - rare; - common.

\begin{tabular}{|c|c|c|c|}
\hline & $\begin{array}{l}\text { Mirošov Horizon } \\
\text { or its equivalent }\end{array}$ & $\begin{array}{c}\text { Chotíkov and Nýřany } \\
\text { coal groups }\end{array}$ & $\begin{array}{l}\text { Nevřeň } \\
\text { coal group }\end{array}$ \\
\hline Alethopteris distantinervosa & $\mathrm{X}$ & & \\
\hline Alethopters kettneri & & $\mathrm{X}$ & \\
\hline Alethopteris lonchitica & $\mathrm{X}$ & & \\
\hline Callipteridium rubescens & $\bullet$ & $\bullet$ & $\mathrm{X}$ \\
\hline Callipteridium armasii & & & $\mathrm{X}$ \\
\hline Neuropteris plicata & $\bullet$ & $\mathrm{X}$ & $\mathrm{X}$ \\
\hline Macroneruopteris scheuchzeri & $\mathrm{X}$ & $\mathrm{X}$ & \\
\hline Linopteris neuropteroides f. neuropteroides & $\mathrm{X}$ & $\mathrm{X}$ & $\mathrm{X}$ \\
\hline Linopteris neuropteroides f. minor & & $\mathrm{X}$ & $\mathrm{X}$ \\
\hline Linopteris obliqua & $\mathrm{X}$ & & \\
\hline Linopteris weigelii & & $\mathrm{X}$ & \\
\hline Odontopteris reichiana & & $\mathrm{X}$ & \\
\hline "Mixoneura" britanica & & $\mathrm{X}$ & \\
\hline
\end{tabular}

\section{Plant migration between intramontane and paralic basins}

Cleal (2008b) argued that there was a dynamic relationship between the medullosalean floras of the lowland and of the intramontane basins of Variscan Euramerica. It is evident that some of the species seen in the Radnice Member originated in the lowland paralic basins in early Westphalian (or earlier) times, and migrated into the CWBB as wetland conditions developed there during late Duckmantianearly Bolsovian times, notably Laveineopteris loshii, Laveineopteris tenuifolia, Alethopteris lonchitica and Linopteris neuropteroides. These tend to be abundant and widespread species in the paralic areas (e.g. Wagner 1968, Cleal \& Shute 1995, Cleal et al. 2009) suggesting they may have been remains of adaptable plants that would have found it easier to extend their ranges into the new upland habitats.

However, there are also examples of taxa that seem to have originated in the intramontane basins and only later extended their ranges into the lowland paralic areas. For instance, Cleal \& Cascales-Miñana (2019) suggested that alethopterids similar to Alethopteris grandinii (Brongniart) Göppert appeared significantly earlier (early Bolsovian) in the intramontane Saar-Lorraine Basin, and only later (middle Asturian) migrated into the lowland paralic areas when there were landscape changes resulting from the Variscan Orogeny. Although A. grandinii has not been reported from the CWBB, there are fragmentary remains of other alethopterids in the Radnice Member that are normally associated with late Asturian and younger floras in the paralic basins: Alethopteris pseudograndinioides and Alethopteris serlii (e.g. Wagner 1968). These Radnice Member fossils are fragmentary and their identification still provisional, but the records are supported by cuticle evidence. They therefore provide some additional support to the idea that at least some of the alethopterids normally associated with late Asturian and later floras in the lowland paralic areas had their origins in more upland wetland habitats.

A similar possible relationship between upland and lowland medullosaleans has also been argued for the smallpinnuled Laveineopteris species (Cleal 2008b, Šimůnek \& Cleal2011), with L. bohemica occurring in late Duckmantian and early Bolsovian floras in the Bohemia-Saar-Lorraine Palaeoprovince, L. rarinervis occurring in late Bolsovian to Cantabrian floras of the Ruhr Palaeoprovince, and both species occurring with overlapping stratigraphical ranges in the Silesia Palaeoprovince. Thomas (1997) has suggested that herbaceous lycophyte species may also have originated in the intramontane basins in Westphalian times and only later extended their ranges into the lowland paralic areas.

There were (as far as we know) no animals that could have facilitated seed dispersal at this time. The large size of the seeds of the medullosaleans (Cleal et al. 2010, Sims 2012) must, therefore, have affected their migration patterns. Water transport by rivers may have been an important vector in some species and might explain the observation that some medullosaleans appear to have migrated downstream from upland to lowland basins. There were, nevertheless, other species that appear to have 
migrated in the opposite direction, presumably in response to changing habitats in the upland basins; as pointed out by Laveine et al. (1993), long-distance migration of medullosaleans may have been achieved simply by seeds being shed and landing not far from the parent plant. Significantly, no medullosalean species occur only in both intramontane basins (CWBB and Saar-Lorraine) but not in at least parts of the foreland basins. This suggests that there was little or no direct migration of these species between the intramontane basins over the intervening highlands. This issue of the long-distance migration of these largeseeded plants, often in response to environmental change, also clearly needs further investigation.

\section{Conclusions}

This first comprehensive taxonomic synopsis of medullosalean pteridosperm foliage from the intramontane CWBB has confirmed that there are clear differences in the balance of species present compared with the lowland paralic basins, but not significantly higher species diversity as was previously suggested (Opluštil \& Cleal 2007). Although there are some species restricted (or mainly restricted) to the CWBB, the differences are mainly due to the absence of several characteristic and abundant, paralic basin species. The analysis also suggests that there is a closer similarity than previously suggested in the medullosalean floras found in the CWBB and the other major, middle-late Westphalian intramontane basin of Variscan Euramerica, in Saar-Lorraine.

The reasons for these differences between the intramontane and paralic basin medullosalean floras is unclear. If there was a significant difference in elevation (and this has still not been fully confirmed) it could have affected temperature or even precipitation patterns. Alternatively, the intramontane basins may have had different substrate conditions due to differences in drainage patterns, and perhaps this altered the species compositions. These differences potentially have wider implications as it has been suggested that plant migration from the intramontane basins may have been a significant factor in the vegetation changes observed in the paralic basins (e.g. Thomas 1997, Cleal et al. 2009, Thomas \& Cleal 2017, Šimůnek \& Cleal 2018, Cleal \& Cascales-Miñana 2019). Evidently, the ecological factors that drove these temporal and palaeofloristic differences among the medullosaleans at this time will require further work.

This study has also suggested that, in contrast with the paralic basins, there was relatively little difference in the peat and clastic substrate vegetation in the CWBB. However, whether there was also a broad similarity in the peat and substrate vegetation in other intramontane basins such as Saar-Lorraine remains unknown.

\section{Acknowledgements}

The authors are grateful for discussion with A. Bashforth (Natural History Museum of Denmark) and the late R.H. Wagner (Cordobá Botanic Gardens) on a number of taxonomic matters dealt with in this paper. The work of the first author (Z $\breve{S})$ was subsidised by the Research Project no. 310420, which is a part of the Strategic research plan of the Czech Geological Survey (DKRVO/ČGS 2018/2022). The second author (CJC) acknowledges a grant from the SYNTHESYS programme (CZ-TAF-6452) that supported his visit to the collections at the National Museum (Prague). The study is a contribution to the National Museum Wales Research Project NS232 "Late Carboniferous terrestrial environments of Variscan Euramerica".

\section{References}

Anderson, M.J. 2001. A new method for non-parametric multivariate analysis of variance. Austral Ecology 26, 32-46. DOI 10.1111/j.1442-9993.2001.01070.pp.x

Anderson, M.J. \& Walsh, D.C. 2013. PERMANOVA, ANOSIM, and the Mantel test in the face of heterogeneous dispersions: what null hypothesis are you testing? Ecological Monographs 83, 557-574. DOI 10.1890/12-2010.1

ANDRÄ, C.J. 1879. Bruchstücke eines Steinkohlenpflanzen von Stradonitz. Verhandlungen des Naturhistorischen Vereins der Preußischen Rheinlande und Westphalens 36, 104.

ANDRÉE, R. 1864. Die Versteinerungen der Steinkohlenformation von Stradonitz in Böhmen. Neues Jahrbuch für Mineralogie, Geologie und Palaeontologie 1864, 160-176.

Barthel, M. 1962. Epidermisuntersuchungen an einigen inkohlten Pteridospermenblättern des Oberkarbons und Perms. Geologie 11, 1-140.

Bashforth, A.R., Drábková, J., Opluštil, S., Gibling, M.R. \& FALCON-LANG, H.J. 2011. Landscape gradients and patchiness in riparian vegetation on a Middle Pennsylvanian braidedriver plain prone to flood disturbance (Nýřany Member, Central and Western Bohemian Basin, Czech Republic). Review of Palaeobotany and Palynology 163, 153-189. DOI 10.1016/j.revpalbo.2010.10.001

BERTRAND, P. 1930. Bassin houiller de la Sarre et de la Lorraine. I. Flore fossile. 1et Fascicule Neuroptéridées. Études des Gîtes Minéraux de la France 1(1), 1-58.

Bertrand, P. 1932. Bassin houiller de la Sarre et de la Lorraine. I. Flore fossile. $2^{\text {éme }}$ Fascicule. Aléthoptéridées. Études des Gîtes Mineraux de la France 1(2), 59-107.

BoyARINA, N.I. 2016. Makrofloristicheske zoni srednego i verkhnego Karbona (Pensil'vanskoi Podsistemi) Donetskogo Basseina. Geologičeskij žurnal 354, 21-35. DOI 10.30836/igs.1025-6814.2016.1.97280

Brongniart, A. 1831. Histoire des végétaux fossiles, 1(5-6). 209-264 pp. G. Dufour \& E. d'Ocagne, Paris.

Brongniart, A. 1834. Histoire des végétaux fossiles, 1(8-9). 289-336 pp. G. Dufour \& E. d'Ocagne, Paris.

Brongniart, A. 1836. Histoire des végétaux fossiles, 1(10). 337-368 pp. G. Dufour \& E. d'Ocagne, Paris. 
Buisine, M. 1961. Contribution a l'étude de la flore du terrain houiller. Les Aléthoptéridées du Nord de la France. Études Géologiques pour l'Atlas Topographie Souterraine 1(4), $1-317$.

Bunbury, C.J.F. 1847. On fossil plants from the Coal Formation of Cape Breton. Quarterly Journal of the Geological Society 3, 423-438. DOI 10.1144/GSL.JGS.1847.003.01-02.44

Cleal, C.J. 1991. Carboniferous and Permian biostratigraphy, 182-215. In Cleal, C.J. (ed.) Plant fossils in gerological investigation. The Palaeozoic. (Series in Applied Geology), Ellis Horwood, Chichester UK.

Cleal, C.J. 2008a. Palaeofloristics of Middle Pennsylvanian lyginopteridaleans in Variscan Euramerica. Palaeogeography, Palaeoclimatology, Palaeoecology 261, 1-14.

DOI 10.1016/j.palaeo.2007.12.010

Cleat, C.J. 2008b. Palaeofloristics of Middle Pennsylvanian medullosaleans in Variscan Euramerica. Palaeogeography, Palaeoclimatology, Palaeoecology 268, 164-180. DOI 10.1016/j.palaeo.2008.03.045

CLEAL, C.J.2018. The Carboniferous coal swamp floras of England: a window on an ancient tropical ecosystem. Proceedings of the Geologists' Association 129, 329-351.

DOI 10.1016/j.pgeola.2017.05.005

Cleal, C.J. \& Cascales-Miñana, B. 2019. Thefloristic relationship between the upland and lowland Carboniferous wetlands of Variscan Euramerica - evidence from some medullosalean pteridosperm fronds. Journal of Palaeogeography 8(14), 1-12. DOI 10.1186/s42501-019-0029-3

Cleal, C.J. \& Shute, C.H. 1992. Epidermal features of some Carboniferous neuropteroid fronds. Review of Palaeobotany and Palynology 71, 171-206.

DOI 10.1016/0034-6667(92)90162-A

Cleal, C.J. \& Shute, C.H. 1995. A synopsis of neuropteroid foliage from the Carboniferous and Lower Permian of Europe. Bulletin of the British Museum (Natural History), Geology Series 51, 1-52.

Cleal, C.J. \& Shute, C.H. 2003. Systematics of the Late Carboniferous medullosalean pteridosperm Laveineopteris and its associated Cyclopteris leaves. Palaeontology 46, 353-411. DOI 10.1111/1475-4983.00303

Cleal, C.J. \& Shute, C.H. 2012. The systematic and palaeoecological value of foliage anatomy in Late Palaeozoic medullosalean seed-plants. Journal of Systematic Palaeontology 10, 765-800.

DOI 10.1080/14772019.2011.634442

Cleal, C.J. \& Thomas, B.A. 1994. Plant fossils of the British Coal Measures. 222 pp. (series Field Guide to Fossils), Palaeontological Association, London.

Cleal, C.J. \& Thomas, B.A. 1999. Tectonics, tropical forest destruction and global warming in the Late Palaeozoic. Acta Palaeobotanica, Supplement 2, 17-19.

Cleal, C.J. \& Thomas, B.A. 2005. Palaeozoic tropical rainforests and their effect on global climates: is the past the key to the present? Geobiology 3, 13-31. DOI 10.1111/j.1472-4669.2005.00043.x

Cleal, C.J. \& Zodrow, E.L. 1989. Epidermal structure of some medullosan Neuropteris foliage from the middle and upper
Carboniferous of Canada and Germany. Palaeontology 32, 837-882.

Cleal, C.J., Dimitrova, T.Kh. \& Zodrow, E.L. 2003. Macrofloral and palynological criteria for recognising the WestphalianStephanian boundary. Newsletters on Stratigraphy 39, 181-208. DOI 10.1127/nos/39/2003/181

Cleal, C.J., Shute, C.H. \& Zodrow, E.L. 1990. A revised taxonomy for Palaeozoic neuropterid foliage. Taxon 39, 486-492. DOI 10.2307/1223109

Cleal, C.J., Zodrow, E.L. \& Mastalerz, M. 2010. An association of Alethopteris foliage, Trigonocarpus ovules and Bernaultialike pollen organs from the Middle Pennsylvanian of Nova Scotia, Canada. Palaeontographica, Abteilung B 283, 73-97. DOI 10.1127/palb/283/2010/73

Cleal, C.J., Opluštil, S., Thomas, B.A. \& Tenchov, Y. 2009. Late Moscovian terrestrial biotas and palaeoenvironments of Variscan Euramerica. Netherlands Journal of Geosciences 88, 81-278. DOI 10.1017/S0016774600000846

Cleal, C.J., Opluštil, S., Thomas, B.A. \& Tenchov, Y. 2011. Pennsylvanian vegetation and climate in tropical Variscan Euramerica. Episodes 34, 3-12.

DOI 10.18814/epiiugs/2011/v34i1/002

DABER, R. 1955. Pflanzengeographische Besonderheiten der Karbonflora des Zwickau-Lugauer Steinkohlenreviers. Geologie 4, 3-95.

D’Angelo, J.A. \& Zodrow, E.L. 2016. 3D chemical map and a theoretical life model for Neuropteris ovata var. simonii (index fossil, Asturian, Late Pennsylvanian, Canada). International Journal of Coal Geology 153, 12-27.

DOI 10.1016/j.coal.2015.11.007

Ettingshausen, C. von 1852. Steinkohlenflora von Stradonitz in Böhmen. Abhandlungen der kaiserlich-königlichen Geologischen Reichsanstalt 1 (Abt. 3, Nr. 4), 1-18.

EtTingshausen, C. von 1854. Die Steinkohlenflora von Radnitz in Böhmen. Abhandlungen der kaiserlich-königlichen Geologischen Reichsanstalt 2 (Abt. 3, Nr. 3), 1-74.

Feistmantel, O. 1874. Die Versteinerungen der böhmischen Ablagerungen mit theilweiser Ergänzung der mangelhaften Formen aus dem Niederschesischen Becken (1). Palaeontographica 23, 1-156.

Feistmantel, O. 1876. Die Versteinerungen der böhmischen Ablagerungen mit theilweiser Ergänzung der mangelhaften Formen aus dem Niederschesischen Becken (3). Palaeontographica 23, 173-316.

Gastaldo, R.A., DiMichele, W.A. \& Pfefferkorn, H.W. 1996. Out of the Icehouse into the Greenhouse: a Late Paleozoic analog for modern global vegetational change. GSA Today 6, 1-7.

Gastaldo, R.A., Pfefferkorn, H.W. \& DiMichele, W.A. 1995. Taphonomic and sedimentologic characterization of roofshale floras. Memoirs of the Geological Society of America 185, 341-352. DOI 10.1130/MEM185-p341

GeInitz, H.B. 1855. Die Versteinerungen der Steinkohlenformation in Sachsen. 61 pp. W. Engelmann, Leipzig. DOI 10.5962/bhl.title.169050

GöpPERT, H. 1836. Systema filicum fossilium. 486 pp. E. Weber, Breslau \& Bonn. 
Gothan, W. 1913. Die oberschlesische Steinkohlenflora. 1 Teil. Abhandlungen der Königlich Preussischen Geologischen Landesanstalt, Neue Folge 75, 1-278.

DOI 10.5962/bhl.title.150544

Gothan, W. 1915. Pflanzengeographisches aus der paläozoischen Flora mit Ausblicken auf die mesozoischen Folgefloren. Englers Botanische Jahrbuch 52, 22-271.

Gothan, W. 1951. Die merkwürdigen pflanzengeographischen Besonderheiten in den mitteleuropäischen Karbonfloren. Palaeontographica, Abteilung B 91, 109-130.

Gothan, W. 1954. Pflanzengeographisches aus dem mitteleuropäischen Karbon. Geologie 3, 219-257.

GutBIER, A. 1835. Abdrücke und Versteinerungen des Zwickauer Schwarzkohlengebirges. 80 pp. G. Richter, Zwickau. DOI 10.5962/bhl.title. 152878

Havlena, V. 1951. Nový druh rodu Alethopteris Stbg. z nýřanské série. Sborník Ústředního Ústavu Geologického 18, 449-486.

Havlena, V. 1953. Neuropteridy českého karbonu a permu. Rozpravy Ústředního Ústavu Geologického 16, 1-168.

Hoffmann, F. 1827. Ueber die Pflanzenreste des Kohlengebirges von Ibbenbühren und vom Piesberge bei Osnabrück, 151-168. In Keferstein, C. (ed.) Teutschland, geognostisch-geologisch dargestellt und mit Charten und Zeichnungen erläutert (4). Landes-Industrie-Comptoirs, Weimar.

Hoth, K., Brause, H., Döring, H., Kahlert, E., Schultka, S., Volkmann, N., Berger, H.-J., Adam, C., Felix, M. \& Wünsche, M. 2009. Die Steinkohlenlagerstätte Zwickau. Bergbau in Sachsen (Bergbaumonographie) 15, 1-160.

Josten, K.-H. 1962. Neuropteris semireticulata, eine neue Art als Bindeglied zwischen den Gattungen Neuropteris und Reticulopteris. Paläontologische Zeitschrift 36, 33-45. DOI 10.1007/BF02989627

Josten, K.-H. 1966. Zur Flora des jüngeren Karbons (Westfal C bis Stefan) in N.W. Deutschland und ihr Vergleich mit andderem Gebieten. Fortschritte in der Geologie von Rheinland und Westfalen 13, 565-644.

Kessler, P. 1916. Die Alethopteriden und Mariopteriden der Saarbrücker Schichten des Saarbeckens. Zeitschrift des Deutsches geologisches Gesellschaft 67, 69-84.

Kvaček, J. \& StrakovÁ, M. 1997. Catalogue of fossil plants described in works of Kaspar M. Sternberg. 201 pp. National Museum, Prague.

LaVeine, J.-P. 1967. Contribution a l'étude de la flore du terrain houiller. Les Neuroptéridées du Nord de la France. Études Géologiques pour l'Atlas Topographie Souterraine 1(5), 1-344.

LAVEINE, J.-P. 1989. Guide paléobotanique dans le terrain houiller Sarro-Lorrain. 154 pp. Houillères du Bassin de Lorraine, Merlebach.

LAVEINE, J.-P. 1997. Synthetic analysis of the neuropterids. Their interest for the decipherment of Carboniferous palaeogeography. Review of Palaeobotany and Palynology 95, 155-189. DOI 10.1016/S0034-6667(96)00033-4

Laveine, J.-P. \& Goubet, P. 1995. Mise au point sur Palaeoweichselia defrancei (Pteridospermée du Carbonifère), à partir d'un bel échantillon récolté dans le bassin houiller du Nord de la France. Sciences géologiques. Bulletin 48, 21-47. DOI 10.3406/sgeol.1995.1920
Laveine, J.P. \& Legrand, L. 2019. Some Late Paleozoic medullosans substantiate the bifurcate semi-pinnate model of frond architecture. Reconstructing the frond of the genus Mixoneura. Palaeontographica, Abteilung B 299, 1-101. DOI $10.1127 / \mathrm{palb} / 2019 / 0063$

Laveine, J.-P. \& Oudoire, T. 2016. Morphological analysis of the Grand'Eury 1890 large frond fragment attributed to Odontopteris reichiana, from the Late Pennsylvanian (Stephanian) of the Gard coalfield (SE of Massif Central, France). Erection of Cyrillopteris gen. nov. Palaeontographica Abteilung B 294, 1-83. DOI 10.1127/palb/294/2016/1

Laveine, J.-P., Coquel, R. \& LoboziaK, S. 1977. Phylogénie générale des Calliptéridiacées (Ptéridospermopsida). Geobios 10, 757-847. DOI 10.1016/S0016-6995(77)80080-6

Laveine, J.-P., Lemoigne, Y. \& Zhang, S.-Z. 1993. General characteristics and paleobiogeography of the Parispermaceae (genera Paripteris Gothan and Linopteris Presl), pteridosperms from the Carboniferous. Palaeontographica, Abteilung B 230, 81-139.

NĚMEJC, F. 1929. O některých nových nálezech ve středočeských uhelných pánvích II. Rozpravy II třidy České Akademie 39(33), 1-8.

NĚMEJC, F. 1930. Floristické poznámky ku stratigrafii některých uhelných pánviček mezi Rokycany a Berounem. Věštník státního geologického ústavu České republiky 6(1), 1-4.

NĚMEJc, F. 1931. Seeds of Alethopteris rubescens Stbg. (i. e. A. Costei Zeill. et auct.). Bulletin international de l'Academie des Sciences de Bohême 41(1), 1-4.

NĚMEJC, F. 1936. Studies on the alethopterids of the Permocarboniferous of Central Bohemia (with remarks on forms collected in other Bohemian coal districts). Věstník Královské České Společnosti Nauk 2, 1-18.

NĚMEJC, F. 1938. Příspěvek ku geologicko-paleontologickému výzkumu mirošovské uhelné pánve. Časopis Národního Muzea, Odd. př́rodověd 112, 307-310.

NĚMEJC, F. 1941. Paleontologicko-stratigrafické př́íspěvky k poznání uhelných revírů severovýchodního okraje plzeňské uhelné pánve. Zprávy geologického ústavu pro Čechy a Moravu $17,184-214$.

NĚMEJC, F. 1949. Odontopterids and mixoneurae of the Permocarboniferous of Bohemia (a preliminary study). Sbornik Národního Musea v Praze 5 B, 3-31.

NĚMEJC, F. 1953. Úvod do floristické stratigrafie kamenouhelných oblastí ČSR. 173 pp. Akademia, Praha.

Novik, E.O. 1952. Kamennougol'naya flora evropeiskoi chasti SSSR. 468 pp. (Paleontologiya SSSR, Novaya Seriya 1), Akademia Nauk SSSR, Moscow.

OpluštiL, S. 2005. Evolution of the Middle Westphalian river valley drainage system in central Bohemia (Czech Republic) and its palaeogeographic implication. Palaeogeography, Palaeoclimatology, Palaeoecology 222, 223-258.

DOI 10.1016/j.palaeo.2005.03.016

Opluštil, S. \& CleAL, C.J. 2007. A comparative analysis of some Late Carboniferous basins of Variscan Europe. Geological Magazine 144, 417-448.

DOI 10.1017/S0016756807003330

Opluštil, S., Lojka, R. \& PŠEnIČKA, J. 2013. Late Variscan 
continental basins in western Bohemia: tectono-sedimentary, climate and biotic archives. Schriftenreihe der Deutschen Gesellschaft für Geowissenschaften 82, 179-201.

Opluštil, S., Martínek, K. \& TasÁryovÁ, Z. 2005. Facies and architectural analysis of fluvial deposits of the Nýřany Member and the Týnec Formation (Westphalian D - Barruelian) in the Kladno-Rakovník and Pilsen basins. Bulletin of Geosciences 80, 45-66.

Opluštil, S., Lojka, R., PšeničKa, J., Yilmaz, Ç. \& Yilmaz, M. 2018. Sedimentology and stratigraphy of the Amasra coalfield (Pennsylvanian), NW Turkey-New insight from a $1 \mathrm{~km}$ thick section. International Journal of Coal Geology 195, 317-346. DOI 10.1016/j.coal.2018.06.013

Opluštil, S., PšeničKa, J., BeK, J., WANG, J., FenG, Z., Libertín, M., ŠImƯNeK, Z., Bureš, J. \& DrÁBKovÁ, J. 2014. T peat-forming plant assemblage preserved in growth position by volcanic ash-fall: a case study from the Middle Pennsylvanian of the Czech Republic. Bulletin of Geosciences 89, 773-818. DOI 10.3140/bull.geosci.1499

Opluštil, S., PšeničKa, J., Libertín, M., Bashforth, A., Šimưnek, Z., Drábková, J. \& DašKová, J. 2009a. A Middle Pennsylvanian (Bolsovian) peat-forming forest preserved in situ in volcanic ash of the Whetstone Horizon in the Radnice Basin, Czech Republic. Review of Palaeobotany and Palynology 155, 234-274.

DOI 10.1016/j.revpalbo.2009.03.002

Opluštil, S., PšeničKa, J., Libertín, M., BeK, J., DašKová, J., Šimưnek, Z. \& DrÁbKová, J. 2009b. Composition and structure of an in situ Middle Pennsylvanian peat-forming plant assemblage buried in volcanic ash, Radnice Basin (Czech Republic). Palaios 24, 726-746.

DOI 10.2110/palo.2008.p08-128r

Opluštil, S., PšEničKa, J., Libertín, M. \& ŠImŮnek, Z. 2007. Vegetation patterns of Westphalian and lower Stephanian mire assemblages preserved in tuff beds of the continental basins of Czech Republic. Review of Palaeobotany and Palynology 143, 107-154. DOI 10.1016/j.revpalbo.2006.06.004

Opluštil, S., Schmitz, M., Cleal, C.J. \& Martínek, K. 2016. A review of the Middle-Late Pennsylvanian west European regional substages and floral biozones, and their correlation to the Geological Time Scale based on new U-Pb ages. EarthScience Reviews 154, 301-335.

DOI 10.1016/j.earscirev.2016.01.004

Opluštil, S., Šimưnek, Z., PšEničKa, J., BeK, J. \& Libertín, M. 2017. A 25 million year macrofloral record (CarboniferousPermian) in the Czech part of the Intra-Sudetic Basin; biostratigraphy, plant diversity and vegetation patterns. Review of Palaeobotany and Palynology 244, 241-307. DOI 10.1016/j.revpalbo.2016.11.011

PeŠEK, J. 1994. Carboniferous of central and western Bohemia (Czech Republic). 60 pp. Czech Geological Survey, Prague.

PešEK, J. 2004. Late Palaeozoic limnic basins and coal deposits of the Czech Republic. (Folia Geologica, Editio Specialid 1), 188 pp. West Bohemia Museum, Pilsen.

Pfefferkorn, H.W., Gastaldo, R.A. \& DiMichele, W.A. 2017. Impact of an icehouse climate interval on tropical vegetation and plant evolution. Stratigraphy 14, 365-376.
Pfefferkorn, H.W., Gastaldo, R.A., DiMichele, W.A. \& Phillips, T.L. 2008. Pennsylvanian tropical floras from the United States as a record of changing climate, 305-316. In Fielding, C.R., Frank, T.D. \& Isbell, J.L. (eds) Resolving the Late Paleozoic Ice Age in time and space. Geological Society of America, Special Paper, 441. Geological Society of America, Boulder CO. DOI 10.1130/2008.2441(21)

Potonié, H. 1899. Lehrbuch der Pflanzenpalaeontologie mit besonderer Rücksicht auf die Bedürfnisse des Geologen, Teil 4. 289-402 pp. F. Dümmler, Berlin.

DOI 10.29041/strat.14.1-4.365-376

Pотоnié, H. 1904. Abbildungen und Beschreibungen fossiler Pflanzen-Reste. Lieferung II (28). Königlich Preussischen Geologischen Landesanstalt, Berlin. DOI 10.5962/bhl.title.66686

Potonié, H. 1909. Abbildungen und Beschreibungen fossiler Pflanzen-Reste. Lieferung VI. Königlich Preussischen Geologischen Landesanstalt, Berlin.

PšEnIČKA, J. \& Opluštil, S. 2011. Fossil flora from the Újezd u Svatého Kř́že coalfield (Bolsovian, Pennsylvanian), Radnice Basin, Czech Republic. Folia 45, 61-93.

RYBA, F. 1904. Beitrag zur Kenntnis des Cannelkohlenflötzes bei Nýřan. Jahrbuch der Kaiserlich-Königlichen Geologischen Reichsanstalt 53, 351-372.

Saltzwedel, K. 1969. Revision der Imparipteris ovata (Hoffmann) Gothan. 1. Teil: Typus- und Typoid-Material vom locus typicus. Argumenta Palaeobotanica 3, 131-162. DOI 10.1515/bgsl.1969.1969.91.1

Schlotheim, E.F. von 1820. Die Petrefactenkunde auf ihrem jetzigen Standpunkte durch die Beschreibung seiner Sammlung versteinerter und fossiler Überreste des Thier- und Pflanzenreichs der Vorwelt erläutert. 437 pp. Gotha.

ŠEtLík, J. 1922. Různotvárnost lístků u druhu Neuropteris plicata Sternb. Sborník Klubu Přirodovědovědeckého v Praze 1921-1922, 79-84.

Š́tLík, J. 1977. Results on recent investigation on the Carboniferous flora of Bohemia, 315-340. In HoLuB, V.M. \& WAGNER, R.H (eds) Symposium on Carboniferous Stratigraphy. Geological Survey, Prague.

Shute, C.H. \& Cleal, C.J. 2002. Ecology and growth habit of Laveineopteris: a gymnosperm from the Late Carboniferous tropical rain forests. Palaeontology 45, 943-972. DOI 10.1111/1475-4983.00270

Sims, H.J. 2012. The evolutionary diversification of seed size: using the past to understand the present. Evolution: International Journal of Organic Evolution 66, 1636-1649. DOI 10.1111/j.1558-5646.2011.01527.x

ŠIMŮNEK, Z. 1988. Varieties of the species Alethopteris grandinioides Kessler from the Kladno Formation (Westphalian C, D, Bohemia). Ćasopis pro mineralogii a geologii 33, 381-394.

ŠIMŮNEK, Z. 1994. Megaflora of tuffaceous interbeds in coal seams of the Nýrrany Member (Westphalian D) at the Dobré štěstí Mine in the Plzeň Basin (Czech Republic). Věstník Českého geologického ústavu 69, 31-46.

ŠIMŮNEK, Z. 2004. The Upper Westphalian flora of the Bohemian Massif (pteridosperms, cordaites and extrabasinal elements). Geologica Balcanica 34, 77-84. 
ŠIMU゚NEK, Z. 2007. Cuticular analysis of medullosalean pteridosperms from the Radnice Member (Pennsylvanian) of the Central and Western Bohemian basins (Czech Republic), 389-402. In Wong, TH.E. (ed.) Proceedings of the $X V^{\text {th }}$ International Congress on Carboniferous and Permian Stratigraphy. Utrecht, the Netherlands, 10-16 August 2003. Royal Netherlands Academy of Arts and Sciences, Amsterdam.

ŠIMŮNEK, Z. 2008. The Asturian and Cantabrian floral assemblages with Cordaites from the Plzeň Basin (Czech Republic). Studia Geologica Polonica 129, 51-80.

ŠimưneK, Z. \& Cleal, C.J. 2002. The taxonomy of middle Westphalian medullosalean foliage known as 'Alethopteris grandinioides early form' from the Central and Western Bohemian Basin. Bulletin of the Czech Geological Survey $77,61-64$.

ŠImŮneK, Z. \& Cleal, C.J. 2004. Small-pinnuled odontopterid medullosaleans from the middle and upper Stephanian of Central Bohemia and Saar-Lorraine. Review of Palaeobotany and Palynology 129, 21-38.

DOI 10.1016/j.revpalbo.2003.11.001

ŠImŮneK, Z. \& Cleal, C.J. 2011. Imparipinnate neuropteroid foliage (Medullosales) from the middle Westphalian of the West and Central Bohemia Coal Basin, Czech Republic. Review of Palaeobotany and Palynology 166, 163-201. DOI 10.1016/j.revpalbo.2011.05.005

ŠIMƯNEK, Z. \& ClEAL, C.J. 2013. The epidermis of cyclopteroid Laveineopteris bohemica (Medullosales) from the Middle Pennsylvanian Radnice Member, Czech Republic. Bulletin of Geosciences 88, 63-67. DOI 10.3140/bull.geosci.1331

ŠIMƯNEK, Z. \& CLEAL, C.J. 2016. The Carboniferous medullosalean pteridosperm Havlenaea praeovata (Němejc) Šimůnek \& Cleal (Stradonice, Central Bohemia) is conspecific with Neuropteris coriacea Ettingshausen. Acta Palaeobotanica 56, 115-119. DOI 10.1515/acpa-2016-0019

ŠImŮneK, Z. \& Cleal, C.J. 2018. Early occurrence of a Pennsylvanian-age medullosalean frond similar to Alethopteris pseudograndinioides in the intra-montane basin of Bohemia. Fossil Imprint 74, 37-44.

DOI 10.2478/if-2018-0003

STERnBerG, K.M. vON 1820-1821. Versuch einer geognostischbotanischen Darstellung der Flora der Vorwelt. 57 pp. F. Fleischer, Leipzig (Part 1 - 1820, Part 2 - 1821).

STERnBERG, K.M. vON 1823-1825. Versuch einer geognostischbotanischen Darstellung der Flora der Vorwelt. 87 pp + xlii pp (Tentamen). E. Brenck's Wittwe, Regensburg (Part 3 1823, Part 4-1825).

SternberG, K.M. von 1833. Versuch einer geognostischbotanischen Darstellung der Flora der Vorwelt, pp. 1-80. J. Spurny, Prague (Parts 5-6).

SternberG, K.M. von 1838. Versuch einer geognostischbotanischen Darstellung der Flora der Vorwelt. 81-220 pp. G. Hässe und Söhne, Prague (Parts 7-8).

Sterzel, J.T. 1881. Paläontologischer charakter der oberen Steinkohlenformation und des Rothliegenden in erzgebirgischen Becken. Naturwissenschaftliche Gesellschaft Chemnitz Bericht 7, 155-270.

Stockmans, F. 1933. Les Neuroptéridées des bassins houiller belges (première partie). Mémoires de Musée Royal d'Histoire Naturelle de Belgique 57, 1-61.

Thomas, B.A. 1997. Upper Carboniferous herbaceous lycopsids. Review of Palaeobotany and Palynology 95, 129-153. DOI 10.1016/S0034-6667(96)00032-2

Thomas, B.A. \& Cleal, C.J. 2017. Distinguishing Pennsylvanianage lowland, extra-basinal and upland vegetation. Palaeobiology and Palaeoenvironments 97, 273-293.

DOI 10.1007/s12549-017-0277-0

WAGNER, R.H. 1962. A brief review of the stratigraphy and floral succession of the Carboniferous in NW. Spain. Compte rendu $4^{e}$ Congrès International de Stratigraphie et de Géologie du Carbonifère (Heerlen) 3, 753-762.

Wagner, R.H. 1963. Sur les Callipteridium du Westphalien supérieur et du Stéphanien. Comptes rendus de l'Académie des Sciences, Paris 257, 719-721.

WAGNER, R.H. 1964a. Stephanian floras in NW. Spain, with special reference to the Westphalian D - Stephanian A boundary. Compte rendu $5^{e}$ Congrès International de Stratigraphie et de Géologie du Carbonifère (Paris, 1963) 1, 835-851.

Wagner, R.H. 1964b. Stephanian B flora from the CiñeraMatallana Coalfield (León) and neighbouring outliers. I: Mixoneura, Reticulopteris, Linopteris and Odontopteris. Notas y Communicaciones del Instituto Geológico y Minero de España 75, 5-56.

Wagner, R.H. 1966. Palaeobotanical dating of Upper Carboniferous folding phases in NW. Spain. Memorias del Instituto Geologico y Minero de España 66, 1-169.

WAGNER, R.H. 1968. Upper Westphalian and Stephanian species of Alethopteris from Europe, Asia Minor and North America. Mededelingen van de Rijks Geologische Dienst, Serie C, III-I 6, 1-188.

Wagner, R.H. 1974. The chronostratigraphic units of the Upper Carboniferous in Europe. Bulletin de la Société Belge de Géologie, de Paléontologie et d'Hydrologie 83, 235-253.

Wagner, R.H. 1977. Comments on the upper Westphalian and Stephanian floras of Czechoslovakia, with particular reference to their stratigraphic age, 441-457. In Holub, V.M. \& Wagner, R.H (eds) Symposium on Carbononiferous Stratigraphy. Geological Survey, Prague.

Wagner, R.H. 1984. Megafloral zones of the Carboniferous. Compte rendu $9^{e}$ Congrès International de Stratigraphie et de Géologie du Carbonifère (Washington, 1979) 2, 109-134.

Wagner, R.H. \& Álvarez-VÁzquez, C. 2008. A revision of the Lower Pennsylvanian Alethopteris lonchitica (auctorum) and its identity with Alethopteris urophylla. Revista Española de Paleontología 23, 157-192.

Wagner, R.H. \& CAstro, M.P. 1998. Neuropteris obtusa, a rare but widespread Late Carboniferous pteridosperm. Palaeontology 41, 1-22.

Wagner, R.H., Fernández Garcia, L.G. \& Eagar, R.M.C. 1983. Geology and palaeontology of the Guardo Coalfield (NE Leon - NW Palencia), Cantabrian Mts. 109 pp. Ministerio de Industria y Energia, Madrid.

Wittry, J., Glasspool, I.J., Béthoux, O., Koll, R \& Cleal, C.J. 2015. A revision of the Pennsylvanian marattialean fern 
Lobatopteris vestita auct. and related species. Journal of Systematic Palaeontology 13, 615-643.

DOI 10.1080/14772019.2014.936915

ZeILler, R. 1899. Étude sur la flore fossile du basin houiller d'Héraclée (Asie Mineure). Mémoires de la Société Géologique de France, Paléontologie 21, 1-91.

DOI 10.5962/bhl.title.110944

Zodrow, E.L. \& ClEAL, C.J. 1998. Revision of the pteridosperm foliage Alethopteris and Lonchopteridium (Upper Carbon- iferous), Sydney Coalfield, Nova Scotia, Canada. Palaeontographica, Abteilung B 247, 65-122.

Zodrow, E.L. \& McCANDLISH, K. 1978. Distribution of Linopteris obliqua in the Sydney Coalfield of Cape Breton Island, Nova Scotia. Palaeontographica, Abteilung B 168, 1-16.

Zodrow, E.L., Tenchov, E.L. \& Cleal, C.J. 2007. The arborescent Linopteris obliqua plant (Medullosales, Pennsylvanian). Bulletin of Geosciences 82, 51-84.

DOI 10.3140/bull.geosci.2007.01.51 